\title{
Article
}

\section{The Role of the State in Contract Law: The Common-Civil Law Divide}

\author{
Mariana Pargendler ${ }^{\dagger}$
}

INTRODUCTION

I. CONTRACT LAW IN COMPARATtVE PERSPECTIVE.

A. Supply and Policing of Substantive Contract Terms ................................................ 150

1. The Duty of Good Faith ............................................................................. 150

2. Mandatory Rules and "Sticky" Default Rules ................................................ 153

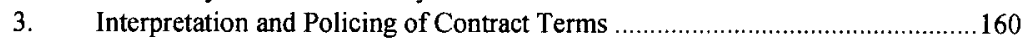

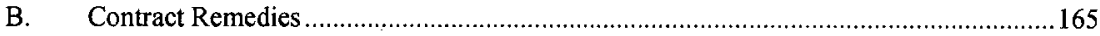

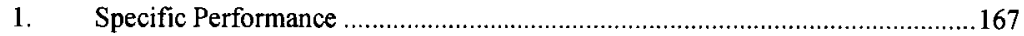

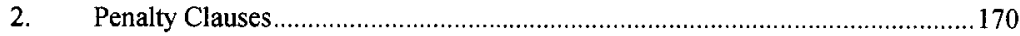

3. Bankruptcy Discharge and "Fresh Start" ..................................................175

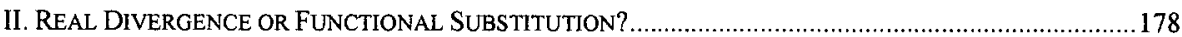

III. THE CIVIL-COMMON LAW DIVIDE AS TO THE ROLE OF THE STATE .......................................... 184

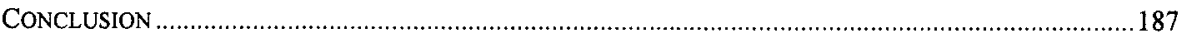

\section{INTRODUCTION}

How do the laws of contract differ across jurisdictions? This question has attracted a tremendous amount of interest over time. In fact, for most of the history of comparative law as a discipline, contract law was the main area of focus of comparative legal study. ${ }^{1}$ This is understandable: international

† Professor of Law, Fundação Getulio Vargas Law School in São Paulo (FGV Direito SP); Global Professor of Law, New York University School of Law. I am grateful for the helpful comments by Ian Ayres, Hannah Buxbaum, Lawrence Cunningham, Kevin Davis, Francisco de Elizalde, Mario Engler, George Georgiev, Luis Gustavo Haddad, Henry Hansmann, Amalia Kessler, Michael Klausner, Rubén Kraiem, Jed Kroncke, Ejan Mackaay, Daniel Markovits, Florian Mőslein, Mathias Reimann, Bruno Salama, Holger Spamann, Udo Reifner, John Reitz, George Triantis, and James Whitman, as well as by participants in the 2016 Annual Comparative Law Work-in-Progress Workshop at the University of Illinois, in the 2016 edition of the Comparative Law and Economics Forum (CLEF), and in the faculty workshop at FGV Direito SP. Bruno Becker and Flávia Kasai provided excellent research assistance. All errors are my own.

1. See, e.g., E. Allan Farnsworth, Comparative Contract Law, in OXFORD HANDBOOK OF COMPARATIVE LAW 899, 900 (Mathias Reimann \& Reinhard Zimmermann eds., 2006) ("Of all areas of law, perhaps none has been subjected to comparative study as consistently, frequently, and intensely as contract law. ... [I]f there is a classical subject-matter of comparative law, that title should be awarded to the law of contract." (citations omitted)). 
commerce has always triggered significant interest in foreign laws, and contracts are a central tool for economic activity. Perhaps unsurprisingly, contract law has also been an area where harmonization and unification efforts have proliferated, though with varying degrees of success. ${ }^{2}$

The vast majority of existing works on comparative contract law are doctrinal in nature, reporting differences and similarities between the legal rules of various countries. ${ }^{3}$ Some studies also go beyond mere description to undertake normative analyses, specifically addressing whether the legal regime of a given jurisdiction is superior, inferior, or equally desirable to those prevailing elsewhere, in view of different histories, cultures, and preferences. However, even the best "functional" analyses, exemplified by the seminal work of Konrad Zweigert and Hein Kötz, operate primarily at the level of legal doctrine, with comparatively little focus on the economic and political environment. ${ }^{4}$

The result is that, even if we have learned a great deal about how contract law differs across jurisdictions, we still know comparatively little about why and so what. The observed differences in the various dimensions of contract law are generally treated as isolated, unrelated, and arbitrary-mostly the product of serendipitous developments in legal history. ${ }^{5}$ Still lacking are broader accounts of how the existing distinctions relate to one another, as well as to other aspects of the legal, economic, and political systems. ${ }^{6}$ Interestingly,

2. Probably the most celebrated harmonization effort in this area is the Vienna Convention for the International Sale of Goods (CISG), which is now in force in more than eighty countries. See Status: United Nations Convention on Contracts for the International Sale of Goods (Vienna, 1980), U.N. COMMISSION ON INT'L TRADE L. (last visited Nov. 10, 2017), http://www.uncitral.org/ uncitral/en/uncitral_texts/sale_goods/1980CISG_status.html. Other prominent initiatives include the UNIDROIT Principles of International Commercial Contracts, whose adoption is voluntary, and the various EU Directives, which have achieved only limited uniformity in specific areas, such as consumer contracts.

3. The literature is too voluminous to be covered in full. For a prominent resource, see 7 INTERNATIONAL ENCYCLOPEDIA OF COMPARATIVE LAW: CONTRACTS IN GENERAL (Arthur von Mehren ed., 1976).

4. See KONRAD ZWEIGERT \& HEIN KÖTZ, AN INTRODUCTION TO COMPARATIVE LAW (3d ed. 1998); see also FORMATION OF CONTRACTS: A STUDY OF THE COMMON CORE OF LEGAL SYSTEMS (Rudolf Schlesinger ed., 1968).

5. See, e.g., Guenter H. Treitel, Remedies for Breach of Contract (Courses of Action Open to a Party Aggrieved), in INTERNATIONAL ENCYClOPEDIA OF COMPARATIVE LAW: CONTRACTS IN GENERAL, supra note $3, \S \S 16-37$ (on specific performance); Farnsworth, supra note 1, at 901 (arguing that the similarities and differences in contract law "were largely the result of historical developments"); Ugo Mattei, The Comparative Law and Economics of Penalty Clauses in Contracts, 43 AM. J. COMP. L. 427,433 (1995) (describing the ban on penalty clauses in the common law as "an accident of legal history").

6. For notable works linking discrete aspects of contract law to the broader political and economic landscape, see Steven Casper, The Legal Framework for Corporate Governance: The Influence of Contract Law on Company Strategies in Germany and the United States, in VARIETIES OF CAPITALISM 387 (David Soskice \& Peter A. Hall eds., 2001) (arguing that non-market forms of firm collaboration explain the existence of the regulatory forms of contract law prevalent in Germany); Katharina Pistor, Legal Ground Rules in Coordinated and Liberal Market Economies, in CORPORATE GOVERNANCE IN CONTEXT: CORPORATIONS, STATES, AND MARKETS IN EUROPE, JAPAN, AND THE U.S. 249, 259-63 (Klaus J. Hopt et al. eds., 2006) (explaining that the role of good faith in enforcing social preferences is part of the "legal ground rules" of coordinated market economies); Aditi Bagchi, The Political Economy of Regulating Contract, 62 AM. J. COMP. L. 687 (2014) (explaining the preference for default rules in the United States and for mandatory rules in Europe in view of heterogeneity, mobility, sectoral composition, and institutional capacity); Catherine Valcke, On Comparing French and English 
this gap in comparative contract law stands in sharp contrast to the state of the art in other areas of comparative study-such as comparative corporate governance and comparative constitutional law-where the various rules and doctrines are increasingly examined jointly and in functional terms, in view of the underlying economic and political structures.?

This Article undertakes to examine in a coordinated manner some of the central - and persisting - doctrinal distinctions in the laws of contract of common and civil law jurisdictions. The classification of legal systems into the legal families of common law and civil law has long played a central role in comparative law scholarship and, more recently, also in the economic literature, which has posited a strong connection between legal traditions and various economic outcomes. ${ }^{8}$ While the importance and continued vitality of legal family categorizations have come under attack, they continue to play a useful descriptive and didactic role in broadly mapping the legal regimes of multiple jurisdictions. ${ }^{9}$

The analysis here will simultaneously examine the distinctions between the common and civil law of contracts that have received the lion's share of attention in both scholarly and practical commentary.$^{10}$ These are:

Contract Law: Insights from Social Contract Theory, 4 J. COMP. L. 69 (2009) (linking the content of the doctrine of mistake under English and French law to philosophical conceptions of the State by Locke and Rousseau, respectively). John Reitz has provided the most comprehensive study of the political economy of contract law to date. His work, which covers significant ground-including employment contracts, price controls, consumer cancellation rights, the regulation of standard terms, the bargain theory of consideration, and the availability of specific performance-concludes that "the common law is more liberal than the civil law." John C. Reitz, Political Economy and Contract Law, in NEW FEATURES IN CONTRACT LAW 247, 273 (Reiner Schulze ed., 2007) [hereinafter Reitz, Political Economy and Contract Law]; see also John C. Reitz, Comparative Law and Political Economy, in COMPARATIVE LAW AND SOCIETY 105 (David S. Clark ed., 2012). The present study, however, goes beyond these earlier findings in numerous respects: it accounts for the central doctrinal distinctions in comparative contract law (such as the strength of the duty of good faith, the treatment of penalty clauses, and the supply of mandatory and default rules by the State), explains the apparent paradox emerging from the common law's reluctance to enforce harsh contractual remedies, and posits the potential existence of functional substitutes to State control of contract terms in bankruptcy law.

7. See, e.g., THE ANATOMY OF CORPORATE LAW: A COMPARATIVE AND FUNCTIONAL APPROACH (John Armour et al. eds., 3d ed. 2017); CURTIS MILHAUPT \& KATHARINA PISTOR, LAW AND CAPITALISM (2008); MARK J. ROE, STRONG MANAGERS, WEAK OWNERS (1994) (concerning comparative corporate governance). On comparative constitutional law, see ALEC STONE SWEET, GOVERNING WITH JUDGES (2000); COMPARATIVE CONSTITUTIONAL LAW (Tom Ginsburg \& Rosalind Dixon eds., 2011).

8. See infra Part III.

9. See, e.g., Beth Ahlering \& Simon Deakin, Labor Regulation, Corporate Governance, and Legal Origin: A Case of Institutional Complementarity?, 41 L. \& SOC'Y REV. 865, 867-68 (2007) (arguing that, while the extant economic literature on legal families is largely ahistorical and inaccurate, "it is important not to throw the baby out with the bathwater"); John C. Reitz, Legal Origins, Comparative Law, and Political Economy, 57 AM. J. COMP. L. 847, 857 (2009) ("[T]he distinction [between civil and common law] continues to be useful for making sense of important aspects of the variety of legal systems in the world.").

10. Items (i) to (v) are certainly among the most recurrent subjects of discussion among comparativists and practitioners. Other popular topics in the comparative literature beyond those covered here are contract formation (especially the comparative role of consideration in the common law and causa in the civil law) and, to a lesser extent, the role of fault in contract law. On contract formation, see JAMES GORDLEY, THE ENFORCEABILITY OF PROMISES IN EUROPEAN CONTRACT LAW (2001) (discussing cause and consideration) and FORMATION OF CONTRACTS: A STUDY OF THE COMMON CORE OF LEGAL SYSTEMS, supra note 4. On the relative importance of fault, see Stefan Grundmann, The Fault Principle as the Chameleon of Contract Law: A Market Function Approach, 107 
(i) The stronger duty of good faith in the civil law;

(ii) The greater number of mandatory contract rules in the civil law;

(iii) The greater intervention in the interpretation and revision of contract terms in the civil law;

(iv) The greater enforcement of penalty clauses in the civil law;

(v) The greater availability of specific performance in the civil law; and

(vi) The greater availability of contract discharge through a "fresh start" in bankruptcy in the common law.

At first sight, it is hard to make sense of these distinctions. The presence of (i) a broader duty of good faith, (ii) more mandatory rules, and (iii) the greater judicial rewriting of contract terms in civil law jurisdictions may lead one to conclude that common law systems provide a stronger role for freedom of contract than do civil law systems - which is indeed a common stereotype in business practice. ${ }^{11}$ Yet this view is not without difficulties. If the common law is truly devoted to sanctity of contract, why does it (iv) deny enforcement to penalty clauses freely agreed by the parties, (v) refuse to grant specific performance as a matter of right (even if the parties specifically choose this remedy), and (vi) more easily discharge contracts in bankruptcy proceedings?

This Article suggests that these differences can be explained by the distinct roles of the State in shaping contract law in common and civil law systems. In civil law systems, the State tends to play a stronger part in all respects. ${ }^{12}$ On the one hand, the State, through legislatures and courts, goes further in providing and policing the substantive terms of the agreement to ensure compliance with broader social values and objectives. On the other hand, once the contract passes muster under this test, the State is also willing to sanction breaches with more severe consequences: namely, by permitting the enforcement of penalty clauses, granting specific performance, and making it more difficult to discharge contractual obligations in bankruptcy proceedings.

Common law systems, by contrast, embrace the opposite approach: legislatures and courts are less willing both to meddle with the terms of the contract and to offer relief to the aggrieved party if voluntary performance is not forthcoming. Under Ian Macneil's conceptualization of the two dimensions

MICH. L. REV. 1583 (2009). The reasons for the observed differences in these areas, as well as their practical significance, remain largely unclear. However, complementarities among the various contract law doctrines of the sort emphasized in the present Article are likely to play a role. For instance, Judge Richard Posner has suggested that the common law provides more lenient contract remedies precisely because, in contrast to the civilian approach, liability for breach of contract in the Anglo-Saxon tradition is strict and does not depend on a showing of fault. See Zapata Hermanos Sucesores, S.A. v. Hearthside Baking Co., 313 F.3d 385, 389-90 (7th Cir. 2002).

11. See, e.g., The Pub.-Private P'ship in Infrastructure Res. Ctr., Key Features of Common Law or Civil Law Systems, WORLD BANK GROUP (Sept. 6, 2016), http://ppp.worldbank.org/publicprivate-partnership/legislation-regulation/framework-assessment/legal-systems/common-vs-civil-law (describing freedom of contract as "extensive" in the common law and "more limited" in the civil law).

12. The present discussion focuses on the role of the State in determining the terms of the agreement and providing remedies for non-performance. Another key part of contract law and enforcement, however, relates to the actual verification of the existence and extent of a breach of contract through fact-finding. This aspect, in turn, is captured by the well-developed literature on comparative civil procedure, which identifies the same pattern observed here in terms of the degree of State involvement: the production of evidence is typically centralized in the judge in the civil law and decentralized to the litigants and their attorneys in the common law. See, e.g., MIRJAN R. DAMAŚKA, THE FACES OF JUSTICE AND STATE AUTHORITY 97-145 (1986). 
of freedom of contract, the common law favors only a narrow version of it, in the sense of "freedom from restraint" in "making or receiving promises." "It is the civil law that embraces a stronger version of the other side of freedom of contract, the "power of contract," which consists in the ability to secure legal sanctions for non-performance. ${ }^{14}$

So how does this overarching pattern relate to prevailing conceptions about common and civil law systems more generally? The character of contract law appears to map the findings of the burgeoning literature on the role of the State across legal traditions, with common law systems boasting more liberal, and civil law systems more interventionist, arrangements of contract law and enforcement. ${ }^{15}$ It is, however, partly in tension with the prevailing notion that the common law necessarily places greater value on-and provides stronger enforcement to-private contracting schemes.

Indeed, once the more modest remedies for breach of contract are taken into account, State support to private contracts in common law jurisdictions looks far more fragile. In other words, the common law's apparent intervention to restrict the remedies available for breach of contract effectively results in a more limited use of the State's coercive powers in contract enforcement. ${ }^{16}$ To put it differently, the common law is not so much supportive of private contracts as it is conducive to private ordering, including with respect to mechanisms for the enforcement of contractual obligations. ${ }^{17}$

At a high level of generality, the different roles of the State in (i) policing the terms of the contract and (ii) calibrating the remedies for non-performance can be viewed as alternative mechanisms to mitigate the effects of harsh contractual commitments. These different approaches are unlikely to guarantee identical results. Yet the analysis offered here highlights how substantive control of contract terms and discharge in bankruptcy can serve as alternative mechanisms for allocating contract risk and mitigating the effects of harsh bargains-a crucial relationship that has been largely overlooked by the existing literature. In this context, the ultimate outcomes in both systems are closer than one would anticipate by focusing on individual rules or styles of State intervention in isolation.

Ascertaining the practical import of these doctrinal differences requires further investigation, including a greater focus on "the law in action." This would be a fruitful area for future research. Although contract institutions play a central role in institutional economics, the existing studies on the subject say very little about legal rules and doctrines-the stuff one learns in law school. In contrast to early works on "law and finance," which examined the effects of

13. Ian R. Macneil, Power of Contract and Agreed Remedies, 47 CORNELL L.Q. 495, 495 (1962). The famous passage by Holmes captures this approach: the common law leaves a party to a contract "free from interference until the time for fulfilment has gone by, and therefore free to break his contract if he chooses." OLIVER WENDELL HOLMES, JR., THE COMMON LAW 272 (2009).

14. Macneil, supra note 13.

15. See infra Part III.

16. For a discussion of the different conceptualizations of the role of the State in contract remedies, see infra Part I.B.

17. For an example of such mechanisms, see infra note 180 and accompanying text. 
particular legal rules of corporate and bankruptcy law, ${ }^{18}$ studies on contract institutions rely exclusively on measures of procedure (i.e., the time, cost, and number of procedures necessary to enforce a contract). ${ }^{19}$ The result is that the existing literature on institutional economics does not have much to say about the comparative contours and economic impact of contract law rules and doctrines; in other words, it is largely "institution free."20 Given the existence of formal variation in the substance of contract laws, however, it seems premature to dismiss their relevance without proper inquiry.

The exposition that follows proceeds in four parts. Part I surveys the core doctrinal differences between civil and common law traditions in the area of contract law and enforcement, as well as the form of State involvement that they implicate. Part II explores the extent to which the diverse approaches of the State to private agreements across legal traditions entail real discrepancies or imply functional substitution. Part III then outlines the general distinctions between common law and civil law jurisdictions as they pertain to the role of the State, and examines how the existing literature on institutional economics has neglected the study of contract law. This Article concludes by reflecting on the future of comparative contract law.

\section{CONTRACT LAW IN COMPARATIVE PERSPECTIVE}

Before proceeding to the analysis of the core areas of divergence between the civil and common law of contracts, some caveats are in order. First, while the discussion that follows focuses on the role of the State in contract law, this very role is intertwined with a distinct conception of contract in the civil law. The Continental approach to contracts expressed in the maxim pacta sunt servanda famously reflects the understanding, inherited from canon law, that a contract entails as much a moral as a legal obligation. ${ }^{21}$ The idea that morality requires parties to live up to their obligations, then, both shapes and complements the role of the State in the civil law of contract.

18. See, e.g., Rafael La Porta, Florencio Lopez-de-Silanes, Andrei Shleifer \& Robert W. Vishny, Law and Finance, 106 J. POL. ECON. 1113 (1998).

19. For a representative study in this tradition, see Daron Acemoglu \& Simon Johnson, Unbundling Institutions, 113 J. POL. ECON. 949 (2005). Consistent with prior works, Acemoglu and Johnson use three procedural proxies to measure contract institutions: (i) the number of procedures necessary to collect on an unpaid check, (ii) an index of procedural complexity and (iii) the number of procedures necessary to resolve a court case on commercial debt. According to the authors, even an "ideal proxy" for contract institutions would simply measure the "costs of enforcing private contracts"- as if the substance of what is actually enforced did not at all matter or vary across jurisdictions. Id. at 951; see also Holger Spamann, Legal Origins, Civil Procedure, and the Quality of Contract Enforcement, 166 J. INSTITUTIONAL \& THEORETICAL ECON. 149 (2010) (using mostly measures of civil procedure to compare the enforceability of contracts in common and civil law jurisdictions).

20. See GeOFFrey M. Hodgson, CONCEPTUAlzing CaPitalism: institutions, EVOLUTION, FUTURE 114 (2015) (highlighting the importance of the legal concept of contract as "legally enforceable obligations," but saying little about which and how obligations are, or should be, enforced).

21. See, e.g., Richard Hyland, Pacta Sunt Servanda: A Meditation, 34 VA. J. INT'L L. 405, 406 (1994) ("According to [one] interpretation of the pacta maxim, then, the role of the law is to provide a state sanction for moral norms."). 
Second, it is important to recognize that the patterns described here likely emerged through historical contingencies in a non-teleological process. They were neither immutable throughout history nor necessarily the product of conscious social engineering dictated by distinct conceptions of the State. Market demands also likely played a role. The point is that, whatever their origin, the resulting differences as to the role of the State turn out to be consistent across different aspects of contract law as well as across other areas of law.

Third, there is substantial complexity and divergence within the broad common law and civil law traditions. ${ }^{22}$ The descriptions that follow should be read as a stylized approximation rather than as a precise depiction of the prevailing regime in any specific jurisdiction. No two jurisdictions have identical contract laws, but this does not deny the utility of legal family classifications to identify broad patterns of variation. The contract law of California, for instance, is closer to the civil law tradition than New York law is, but closer to New York law than most civil law jurisdictions. ${ }^{23}$

Finally, there is widespread (if not universal) consensus that civil and common law systems have gradually converged over time, mitigating differences that were arguably sharper in the past. ${ }^{24}$ This claim is particularly frequent with respect to the law of contracts, an area in which crossfertilization and common law borrowings of civilian institutions have been most conspicuous. ${ }^{25}$ Nevertheless, it is fair to say that certain relative differences across legal traditions persist-even if they might be less pronounced than they once were-and continue to deserve the attention of comparative law scholars and practitioners. ${ }^{26}$ Relative differences are, after all,

22. For a recent volume highlighting the differences between U.S. and U.K. contract law, see COMPARATIVE CONTRACT LAW: BRITISH AND AMERICAN PERSPECTIVES (Larty DiMatteo \& Martin Hogg eds., 2016).

23. Interestingly, California has a civil code and was influenced by the civil law in other aspects of private law (such as its land regime and community property system). LAWRENCE $M$. FRIEDMAN, A HISTORY OF AMERICAN LAW 365 (3d ed. 2005). And it turns out that California is closer to the civil law system than New York law along most of the dimensions examined below, such as by imposing more mandatory rules than restricting freedom of contract, by relying on a stronger version of the duty of good faith, by embracing a more contextualist (as opposed to formalist) approach to contract interpretation, and, at least in theory, by more liberally enforcing penalty clauses. See Mattei, supra note 5 , at $433 \mathrm{n} .16$ (referring to the "shy steps in the direction of reform" for the greater enforcement of penalty clauses in California); Geoffrey P. Miller, Bargains Bicoastal: New Light on Contract Theory, 31 CARDOZO L. REV. 1475 (2010) (describing the main differences between the New York and California law of contracts).

24. See, e.g., Holger Spamann, Contemporary Legal Transplants: Legal Families and the Diffusion of (Corporate) Law, 2009 BYU L. REV. 1813, 1814-15 (describing the growing consensus among sophisticated comparativists that "there are few if any relevant differences between common and civil law today"). But see Pierre Legrand, European Legal Systems Are Not Converging, 45 INT'L \& COMP. L.Q. 52, 62 (1996) (challenging the "convergence thesis" regarding civil and common law systems).

25. Barry Nicholas, Rules and Terms-Civil Law and Common Law, 48 TUL. L. REV. 946, 946 (1974) (" $[1] \mathrm{t}$ is in the law of contract . . . that Common lawyers have most often looked to Roman or Civil law.").

26. For a volume dedicated to the practical difficulties that emerge when Anglo-Saxon contract models are governed by the more interventionist laws of civil law jurisdictions, see BOILERPLATE CLAUSES, INTERNATIONAL COMMERCIAL CONTRACTS AND THE APPLICABLE LAW 181-82 (Giuditta Cordero-Moss ed,, 2011). 
the stuff of comparative law. ${ }^{27}$

I will address these key persisting differences in turn below. For expositional purposes, ${ }^{28} \mathrm{I}$ will provisionally group the distinctions into two larger categories of legal doctrines and rules that (i) dictate the substantive terms of the agreement-that is, the primary rights and duties of the contracting parties, and (ii) specify contract remedies - the legal consequences available to the aggrieved party in the event of a breach of contract.

\section{A. Supply and Policing of Substantive Contract Terms}

\section{The Duty of Good Faith}

Of all topics in the comparative law of contracts, perhaps none has attracted as much interest in recent times as the duty of good faith. When Alan Farnsworth described his experience as the U.S. delegate in the harmonization efforts leading to the United Nations Convention for the International Sale of Goods (CISG) and the UNIDROIT Principles of International Commercial Contracts, the duty of good faith topped his list of key distinctions between the common and the civil laws of contracts. ${ }^{29}$ Reinhard Zimmermann and Simon Whittaker have devoted an entire volume to a functional inquiry, based on hypothetical fact patterns, into the scope of the duty of good faith in European issue for which, at least in principle, there appears to be a "rather clear-cut civil law/common law divide." 30

While the duty of good faith famously performs multiple functions in contract law (as in other areas of law), I will focus here on its role in shaping the meaning and scope of contract performance. ${ }^{31}$ Specifically, the main issue is whether, and to what extent, good faith operates as a source of implied contractual duties of cooperation and collaboration beyond those expressly provided in the agreement. So understood, good faith epitomizes the type of open-ended standard which is often associated with altruistic concerns, as opposed to the individualistic values habitually linked to clear rules. ${ }^{32}$

In broad terms, the consensus is that civil law jurisdictions presently contemplate a more expansive application of the duty of good faith in contract

27. James Q. Whitman, The Two Western Cultures of Privacy: Dignity Versus Liberty, 113 YALE L.J. 1151, 1163 (2004) ("But the issue is not whether there is an absolute difference. Comparative law is the study of relative differences.").

28. Although traditional in the literature, scholars have criticized this dichotomy between substantive contract terms and the remedies available in the event of a breach. For a discussion, see infra notes 237-240 and accompanying text.

29. E. Allan Farnsworth, A Common Lawyer's View of His Civilian Colleagues, 57 LA. L. REV. 227, 234 (1996).

30. GOOD FAITH IN EUROPEAN CONTRACT LAW 15 (Reinhard Zimmermann \& Simon Whittaker eds., 2000) (finding significant convergence in the outcome of various hypotheticals).

31. The duty of good faith in the civil law is sufficiently broad to accommodate various other functions as well, such as imposing a duty of care in pre-contractual negotiations and discouraging contradictory behavior that violates the other party's legitimate expectations (as expressed by the Latin maxim non venire contra factum proprium), a function that in the common law is usually fulfilled by the doctrine of estoppel. 1685 (1976).

32. Duncan Kennedy, Form and Substance in Private Law Adjudication, 89 HARV. L. REV. 
law. ${ }^{33}$ This is not to deny that the distinction in the scope and force of the duty of good faith across different traditions is merely one of degree. Not all civil law jurisdictions embrace the duty of good faith with similar enthusiasm. Germany-where the duty of good faith operates as a "judicial oak that overshadows the contractual relationship of private parties"34_led the way, with some jurisdictions, such as Brazil, embracing it with even greater fervor, and others, like France, more reluctantly following. ${ }^{35}$

At the same time, the duty of good faith is not alien to the common law world. The Uniform Commercial Code (UCC) in the United States-which, among other things, harmonized state law with respect to the sale of goodsspecifically provides for an obligation of good faith in the performance and enforcement of every contract. ${ }^{36}$ The UCC's embrace of good faith was not accidental but rather the product of German influence through its Germanophile draftsman, Karl Llewellyn. ${ }^{37}$ Moreover, contractual good faith is relevant outside of the UCC context as well, with numerous U.S. judicial decisions relying on the common law duty of good faith to fill gaps in the contract and impose duties of conduct beyond those expressly articulated by the agreement. ${ }^{38}$ Nevertheless, most observers would probably agree that U.S. courts use good faith to imply contractual duties with less frequency and gusto than their civilian counterparts do.

English law was historically more hostile to the duty of good faith in contract law, "adamantly [refusing] to recognize any such duty of good faith whatsoever." 39 Admittedly, as a rare common law jurisdiction in the European Union prior to "Brexit," it was hard for England to resist the gravitational pull of good faith in EU harmonization efforts in contract law. ${ }^{40}$ Full convergence remained elusive, however, with Gunther Teubner predicting that good faith in

33. See, e.g., Ejan Mackaay, Good Faith in Civil Law Systems: A Legal-Economic Analysis (Cirano Sci. Series, Paper No. 2011s-74, 2011), http://ssm.com/abstract=1998924 (noting the greater reluctance towards good faith in common law countries).

34. Werner F. Ebke \& Bettina M. Steinhauer, The Doctrine of Good Faith in German Contract Law, in GOOD FAITH AND FAULT IN CONTRACT LAW 171, 171 (Jack Beatson \& Daniel Friedmann eds., 1995).

35. On the duty of good faith in Brazilian law, see JUDITH MARTINS-COSTA, A BOA-FÉ NO DireIto PRIVADO ( $2 \mathrm{~d}$ ed. 2015). On the duty of good faith in France, see GoOD FAITH IN EUROPEAN CONTRACT LAW, supra note 30 , at 39 .

36. U.C.C. § 1-304 (AM. LAW INST. \& UNIF. LAW COMM’N 1977).

37. For an analysis of the degree of German influence on Llewellyn's conception of the UCC, see Shael Herman, Llewellyn the Civilian: Speculations on the Contribution of Continental Experience to the Uniform Commercial Code, 56 TUL. L. REV. 1125 (1982); James Q. Whitman, Note, Commercial Law and the American Volk: A Note on Llewellyn's German Sources for the Uniform Commercial Code, 97 YALE L.J. 156 (1987).

38. For a few representative examples, see KLT Indus., Inc. v. Eaton Corp., 505 F. Supp. 1072, 1079-80 (E.D. Mich. 1981) and Mkt. St. Assocs. v. Frey, 941 F.2d 588, 595 (7th Cir. 1991). For a discussion of these and other cases, see Mariana Pargendler, Modes of Gap Filling: Good Faith and Fiduciary Duties Reconsidered, 82 TUL. L. REV. 1315 (2008). On the recognition of a general duty of good faith per Section 2015 of the 1979 Restatement (Second) of Contracts, see Robert S. Summers, The General Duty of Good Faith-Its Recognition and Conceptualization, 67 CORNELL L. REV. 810 (1982).

39. Farnsworth, supra note 29 , at 235.

40. See, e.g., The Unfair Terms in Consumer Contracts Regulations 1994, SI 1994/3159, art. 4 (Eng.) (implementing Council Directive 93/13/EEC of 5 April 1993 on Unfair Terms in Consumer Contracts, 1993 O.J. (L 95) 29 (EC)). 
England would serve more as a "legal irritant" than a "legal transplant" proper. $^{41}$

Beyond mandatory EU regulations and legislation implementing directives, English law was largely impervious to Continental ideas in contract law, including its notions of good faith. ${ }^{42}$ In fact, existing efforts to market England as the jurisdiction of choice for dispute resolution in commercial matters specifically identify "the absence of any general duty of good faith" under its law as a key selling point. ${ }^{43}$ While recent decisions suggest that English courts are becoming gradually more receptive to the duty of good faith in contract law, ${ }^{44}$ it is still not possible to discern a shift toward the Continental use of the concept, ${ }^{45}$ which is now less likely to take place given the United Kingdom's decision to leave the European Union. ${ }^{46}$

Whether the expansive civilian or restrictive common law approach to good faith is more desirable from a normative perspective is still an open question. Economic theory posits that real-world contracts are necessarily incomplete: the combination of positive transaction costs and bounded rationality prevents parties from specifying optimal obligations for every possible state of the world. In this context, courts could promote efficiency by using good faith to provide parties with the terms they would have bargained for absent the constraints of transaction costs and limited foresight. ${ }^{47}$

Indeed, scholars have argued that the duty of good faith may achieve precisely this result: by curbing opportunistic behavior, it enables civilian parties to save contracting costs and write shorter contracts that achieve the same results as their prolix common law counterparts. ${ }^{48}$ Yet civilian courts

41. Gunther Teubner, Good Faith in British Law or How Unifying Law Ends Up in New Divergences, 61 MOD. L. REV. 11, 12 (1998).

42. Hugh Beale, The Impact of Decisions of the European Courts on English Contract Law: The Limits of Voluntary Harmonization, 18 EUR. REV. PRIV. L. 501, 513-14 (2010).

43. THE LAW SOC'Y OF ENG. \& WalES, ENGLAND AND Wales: THE JuRISDiction of CHOICE (2007), http://www.eversheds.com/documents/LawSocietyEnglandAndWalesJurisdictionOf Choice.pdf.

44. See, e.g., Yam Seng Pte Ltd. v. Int'l Trade Corp. [2013] EWHC (QB) 111 [153] (Eng.) ("[T]he traditional English hostility towards a doctrine of good faith in the performance of contracts, to the extent that it still persists, is misplaced.").

45. See Mid Essex Hosp. Serv. NHS Trust v. Compass Grp. U.K. \& Ireland Ltd. [2013] EWCA (Civ) 200 [105] (Eng.) ("I start by reminding myself that there is no general doctrine of 'good faith' in English contract law .... If the parties wish to impose such a duty they must do so expressly."); see also Ewan McKendrick, Good Faith in the Performance of a Contract in English Law, in COMPARATIVE CONTRACT LAW: BRITISH AND AMERICAN PERSPECTIVES, supra note 22, at 207-08.

46. Catharine MacMillan, The Impact of Brexit upon English Contract Law, 27 KING's L.J. 420 (2016) (predicting that, following Brexit, "[g]ood faith . . . has a more limited future in English law than it otherwise would have had").

47. Frank H. Easterbrook \& Daniel R. Fischel, Contract and Fiduciary Duty, 36 J.L. \& ECON. 425 (1993). For a summary of this argument as it applies specifically to good faith in contract law, see Pargendler, supra note 38.

48. Claire A. Hill \& Christopher King, How Do German Contracts Do as Much with Fewer Words?, 79 CHI.-KENT L. REV. 889 (2004). But see John H. Langbein, Comparative Civil Procedure and the Style of Complex Contracts, 35 AM. J. COMP. L. 381, 385-92 (1987) (crediting the difference in length between U.S. and German contracts to the superiority of the German system of civil procedure). In Langbein's view, parties in the United States write longer contracts in an attempt to prevent disputes and thereby escape what he views as a "catalogue of procedural horrors" plaguing U.S. litigation. Id. at 390. 
might also get parties' preferences wrong and, in implying duties, prevent the parties from "getting . . . the deal they want."49 Moreover, the use of good faith by civilian courts is by no means limited to gap filling; good faith also occasionally serves to override contract terms that are deemed unfair or otherwise unsuitable. Therefore, an alternative explanation for differences in contract style is that civilian lawyers may more easily "resign themselves . . . to the futility of influencing bureaucracies, and bureaucratic judges," writing shorter contracts as a result. ${ }^{50}$

There is little question, however, that a stronger doctrine of good faitheither by filling gaps in the contract or by overriding express contract terms altogether-implies a stronger role for the State in contract adjudication. It replaces private decision-making with collective decision-making inspired by social values, be it desirable from the parties' perspectives or not. It is this feature that, for Katharina Pistor, makes the duty of good faith a legal foundation of coordinated market economies-one that helps explain their observed connection with civil law systems. ${ }^{51}$

\section{Mandatory Rules and "Sticky" Default Rules}

Beyond good faith and other doctrines that permit judges to rewrite or discharge contracts ex post, another distinctive feature of contract law in civil law countries is the presence of numerous statutory rules on the various "types" of contracts. "Typical" contracts are categories of agreements that usually include sale, exchange, loan, agency, transportation, and insurance contracts, among others. In fact, the classification between "typical" contracts (which are regulated by statute, usually the Civil Code itself) and "atypical" contracts (which are not) is paramount in the civil law of contracts. ${ }^{52}$ While in the common law, contracts are regarded as a unitary phenomenon, the concept of types of contracts is so fundamental in the civil law that law schools in these jurisdictions have traditionally devoted one or more mandatory courses to their legal regime alone-beyond the introductory courses on civil obligations and general principles of contract law. ${ }^{53}$

Although contract types are pervasive in civil law jurisdictions, the relative importance of the distinction between typical and atypical contracts varies across countries. The Italian Civil Code of 1942 places the most

49. Hill \& King, supra note 48 , at 890 .

50. Thomas Lundmark, Verbose Contracts, 49 AM. J. CoMP. L. 121, 131 (2001). Conversely, a sharper distrust of the State is another reason for having parties specify exactly the deal they want and for favoring individualized, libertarian solutions. $I d$. at 130 .

51. Pistor, supra note 6, at 259.

52. Some jurisdictions employ the terms "nominate" or "innominate" contracts to describe the same phenomenon, whereas others use the expressions nominate or innominate to designate whether the statute or commercial practice give a name to the specific contract. Under the latter usage, a contract can be nominate but still atypical, if its terms are not regulated by statute.

53. See, e.g., Kalvis Torgans \& Amy Bushaw, Some Comparative Aspects of Contract Law in Civil and Common Law Systems, 12 INT'L LEGAL PERSP. 37, 50-51 (2001-2002) (discussing how the classification into types of contracts is an important part of legal education in Latvia, but not in the United States). 
dramatic emphasis on this concept. Promulgated at the apex of the fascist era, it allows parties to enter into atypical contracts only insofar as they attain interests that deserve protection from the legal system. ${ }^{54}$ Emilio Betti, a prominent commentator, clarified that the statutory requirements meant that the parties to an atypical contract had to prove the existence of a general interest of social economic character, from an objective standard, accompanied by a general social practice. ${ }^{55}$ Freedom to choose contractual types by no means implied an absolute freedom to choose whatever content; it merely meant that parties could choose among the legal types and established social practices. Betti expressly argued that, just like in Roman law, innovative one-shot deals, which he called "sporadic drives," were not enforceable by the legal system. ${ }^{56}$

Even though Italy is, in many respects, the archetypal civil law jurisdiction, ${ }^{57}$ its radical and collectivist approach to contract models is not representative of the modern civil law of contracts. The wave of nineteenthcentury codifications in the civil law arguably introduced contract types as a remnant of Roman law, ${ }^{58}$ not as an instrument for collectivistic ideology. Other civil law countries have long recognized that the parties have the right to enter into enforceable atypical contracts if they so wish without further conditions other than not violating general contract principles and the public order. ${ }^{59}$ Nevertheless, civilian scholars in France and Brazil have also expressed strong skepticism from both positive and normative perspectives towards atypical contracts that lack a statutory basis. ${ }^{60}$

54. Codice civile [C.C.] [Civil Code], art. 1322 (It.) ("Autonomia contrattuale-Le parti possono liberamente determinare il contenuto del contratto nei limiti imposti dalla legge . . . Le parti possono anche concludere contratti che non appartengono ai tipi aventi una disciplina particolare, purché siano diretti a realizzare interessi meritevoli di tutela secondo l'ordinamento giuridico." ["Contractual Autonomy-The parties may freely determine the content of the contract within the limits of the law (and corporate rules). The parties may also conclude contracts that do not belong to the types of a particular discipline, provided that they be directed at securing interests protected under the legal order."]).

55. Emilio Betti, La tipicità dei negozi giuridici romani e la cosidetta atipicità del diritto odierno [The Typicality of Roman Legal Transactions and the So-Called Atypicality of Today's Law], in DiRTTTO, METODO, ERMENEUTICA [LAW, METHOD, HeRMENEUTICS], 325, 358-59 (Giuliano Crifó ed., 1991).

56. Id. at 348 .

57. JOHN HENRY MERR YMAN, THE CIVIL LAW TRADITION: AN INTRODUCTION TO THE LEGAL SYSTEMS OF WESTERN EUROPE AND LATIN AMERICA 57 (1985).

58. See, e.g., Barry Nicholas, The French Law of CONTRACt 49 (1992) ("French law began with the Roman system of typical contracts and superimposed on it the unitary consensual principle that any agreement is a contract.").

59. Brazil's Civil Code of 2002 found it worthwhile to expressly state that "it is lawful for the parties to enter into atypical contracts, subject to the general provisions of this Code." CoDIGo CIVIL [C.C.] [CIVIL CODE], art. 425 (Braz.). Parties could, of course, enter into atypical contracts under the previous civil code regime despite the absence of an express statutory permission. However, the very fact that the legislature found it relevant to spell out such a possibility illustrates the relevance of the distinction in civil law countries.

60. Marcel Planiol, Classifications synthétique des contrats, 33 REVUE CRUTIQUE DE LEGISLATION ET DE JURISPRUDENCE 470, 477-78 (1904) (Fr.) (postulating that parties could not possibly create new atypical contracts, since all contractual forms could be traced back to a type or to a combination of known types); Paulo da Silva Pinto, Dos Contratos Atípicos, 95 REVISTA Forense 1415 (1943) (Braz.) ("Nothing is more laudable that the constant efforts of true jurists, who, at any cost, attempt to keep unaltered the solid construction of the legal intuition of the Romans and of the long centuries of scientific elaboration that have preceded us. This contrasts with the laziness or indifference 
The civil law today consistently recognizes and enforces both typical and atypical contracts. Still, this categorization remains consequential, because so long as a contract is typical-and, as the name suggests, most contracts are typical-the mandatory and default rules provided in the civil code or special statutes apply. Typical contracts presumably come with "pre-packaged terms." ${ }^{\text {161 }}$ The presence of such rules, in turn, matters in different ways. Some of these rules are mandatory and, therefore, clearly represent a State-imposed limitation on freedom of contract. Take, for instance, Article 598 of the Brazilian Civil Code, which limits the term of service contracts to a maximum of four years, ${ }^{62}$ or Articles 1506 and 1516 of the Argentinean Civil Code, which impose a minimum term of four years for franchise contracts. ${ }^{63}$

Traditionally, most statutory rules have the nature of default rules (jus dispositivum)-meaning that they apply only "in default" of the parties" agreement, which can freely provide otherwise. However, even default rules can be "sticky" in practice, ${ }^{64}$ and, as such, constrain freedom of contract. For instance, scholars have documented the tendency of Taiwanese courts to either hastily qualify a contract as typical under the Taiwan Civil Code, irrespective of its nature or purpose, or to aggressively employ analogies to incorporate the Code's default provisions into the agreement. ${ }^{65}$

There are at least three sets of reasons for such stickiness of default rules. First, courts everywhere often tend to think that default rules embody some kind of superior notion of fairness and, as a result, apply them contrarily to the terms of the deal. ${ }^{66}$ This pattern is especially visible in civil law countries, like Brazil and China, where the default or mandatory character of such rules is often not explicit in the statutory text. ${ }^{67}$ Second, regulators may purposefully

of those that comfortably try to escape the first difficulty by saying that any less known or still imperfectly characterized contract belongs in the category of innominate contracts, as if this were a means to make the theoretical construction of the new type of agreement unnecessary.").

61. Valcke, supra note 6 , at 74 .

62. Some (though not all) courts have interpreted this provision narrowly to exclude contracts between legal persons from its application. See, e.g., T.J.S.P., Ap. Civ. No. 9081895-20.2006.8.26.0000, Relator: Des. Ferraz Felisardo, 18.05.2011, DIÁRIO DA JUSTIÇA [D.J.] 23.05.2011.

63. Bret Lowell \& Abhishek Dubé, Argentina's New Franchise Law: Unusual and Unclear, DLA PIPER (May 4, 2015), http:/www.dlapiper.com/en/mexico/insights/publications/2015/05/ argentina-new-franchise-law (describing this rule as "unusual").

64. See, e.g., Omri Ben-Shahar \& John A. E. Pottow, On the Stickiness of Default Rules, 33 FLA. ST. U. L. REV. 651 (2006).

65. Wen-yeu Wang, The Evolution of Contract Law in Taiwan: Lost in Interpretation?, in PRIVATE LAW IN CHINA AND TAIWAN: LEGAL AND ECONOMIC ANALYSES 100 (Yun-chien Chang et al. eds., 2017).

66. See, e.g., Alan Schwartz \& Robert E. Scott, Contract Theory and the Limits of Contract Law, 113 YALE L.J. 541, 596 (2003).

67. Take, for instance, Article 623 of the Brazilian Civil Code, which applies to construction contracts: the rule permits the owner to terminate the agreement after construction has begun by paying expectation damages to the contractor. Legal scholars have disagreed on whether this rule is default or mandatory in character, and no consensus has yet emerged. For China, see Jing Leng \& Wei Shen, The Evolution of Contract Law in China: Convergence in Law but Divergence in Enforcement?, in PRIVATE LAW IN CHINA AND TAIWAN, LEGAL AND ECONOMIC ANALYSES, supra note 65, at 63. The same ambiguity and uncertainty exists in current efforts at legislative reform in France. See, e.g., Bénédicte Fauvarque-Cosson, The French Contract Law Reform in a European Context, 2014 EƠTVÖS LORÁND U. L.J. 59, 71 (noting that France's recent project to reform the law of obligations does not differentiate between mandatory and default rules). By contrast, codifications of contract law in common law 
deter parties from deviating from default rules by imposing demanding procedures for parties to opt out. ${ }^{68}$ Third, regardless of judicial preferences and regulatory strategies, the findings of behavioral economics suggest that the cognitive biases of the parties themselves, such as "anchoring" and "endowment" effects, discourage deviation from default rules where they exist. ${ }^{69}$

In view of the prevalence of codified rules on contract types, civil lawyers generally feel constrained from adopting "a more free-wheeling and particularized" discussion of contract terms and resort to the statutory models instead. ${ }^{70}$ In other words, the State-supplied terms frame the parties' choice. ${ }^{71}$ It is probably no coincidence that most atypical contracts in civil law jurisdictions are so-called "-ing contracts"-leasing, franchising, factoring, engineeringwhich retain their English names on foreign soil, hence revealing their origin in a common law contracting environment that is less constrained by Statesupplied terms. ${ }^{72}$

Compounding the problem, the determination of whether a contract is typical or atypical is not as straightforward as it may first appear. The question is a familiar one of qualification: as a rule, the name the parties give to their contract is not dispositive for purposes of classification. Even if the parties call the contract $x$, the court may consider that it is, in essence, a contract $y$, and thereby apply the latter legal regime. ${ }^{73}$ Moreover, an atypical contract may be mixed - i.e., a combination of two or more typical contracts - in which case the different default rules of its components shall apply. Only an atypical contract that is truly sui generis will be subject exclusively to its terms and to general

countries, such as the U.S. Uniform Commercial Code, are often more explicit about the default or mandatory character of their provisions.

68. FLORIAN MÖSLEIN, DisPOSITIVES RECHT: ZWECKE, STRUKTUREN UND METHOdEN 218-20 (2011); Ian Ayres, Regulating Opt-Out: An Economic Theory of Altering Rules, 121 YALE L.J. 2032, 2045 (2012).

69. See, e.g., Marcel Kahan \& Michael Klausner, Path Dependence in Corporate Contracting Increasing Returns, Herd Behavior and Cognitive Biases, 74 WASH. U. L.Q. 347, 363 (1996); Russell Korobkin, Inertia and Preference in Contract Negotiation: The Psychological Power of Default Rules and Form Terms, 51 VAND. L. REV. 1583, 1584 (1998); Russell Korobkin, The Status Quo Bias and Contract Default Rules, 83 CORNELL L. REV. 608 (1998).

70. Rubén Kraiem, Leaving Money on the Table: Contract Practice in a Low-Trust Environment, 42 COLUM. J. TRANSNAT'L L. 715, 746 (2004).

71. Id. ("Although not all such codified terms are prescribed, the notion of 'contracting out' is simply not particularly current. If anything, there is a strong preference for what one might call 'contracting around'-using complex contracting devices or particular types of contracts to obscure the substance of a transaction and thus claim that it should be subject to a different set of interpretive norms.").

72. Bernard Audit, L'américanisation du droit: Introduction, 45 ARCHIVES DE PHILOSOPHIE DU DROIT 7, 9 (2001) (referring to "les contrats en 'ing "); BASEL MARKESINIS, HANNES UNBERATH \& ANGUS JOHNSTON, THE GERMAN LAW OF CONTRACT: A COMPARATIVE TREATISE 163 (2006) (noting that prominent atypical contracts such as Factoring, Leasing, and Franchising retain their English names under German practice).

73. Jacques Henrot, Classification and General Rules of Construction in French Law, in DRAFTING AND ENFORCING CONTRACTS IN CIVIL AND COMMON LAW JURISDICTIONS 56-57 (Kojo Yelpaala et al. eds., 1990) (observing that the Paris Court of Appeal had recently held that a contract described by the parties as a partnership agreement was in fact a sale of shares with the seller retaining some of the usual shareholders' rights, even though the parties never contemplated such classification). 
contract principles. ${ }^{74}$ Even sui generis contracts, however, soon become the object of scholarly books and treatises concerning their regulation, which may soon lead to new de facto default or mandatory rules. Argentina's new Civil Code of 2015 typified previously atypical contracts, such as leasing and franchising, a move praised by local commentators as contributing to "legal certainty."75

To be sure, a focus on general contract statutes and codes could lead one to underestimate the degree of influence of soft law or outright State interference on contract practices and terms in the Anglo-Saxon world. First, the common law is a rich source of default rules and standards for different types of contracts, even if the result is still far less comprehensive than that found under civil law legislation. ${ }^{76}$ Second, there may be soft law on the topic. In the United States, the American Law Institute has produced not only a general Restatement of Contracts, now in its second edition, but also specific principles on software and insurance contracts. Third, there is significant legislation in this area.

Beyond the various default and mandatory rules applicable to sales and leases under the UCC, a number of constraints derive from specialized federal laws in the United States, such as the Federal Trade Commission Act of 1914, the Truth in Lending Act of 1968, and, more recently, the Dodd-Frank Act of $2010 .^{77}$ There are also numerous U.S. state statutes dedicated to specific modalities of contract and to consumer protection generally, to the point of raising concerns about regulatory overkill. ${ }^{78}$ Unfortunately, however, comparative studies on regulatory constraints are scarcer than those on contract law doctrine, which makes it hard to draw definitive conclusions about the results of these efforts.

Even so, the emerging works on the contractual dimensions of consumer protection have concluded that the legal regime embraced by EU directiveswhich are heavily inspired by civil law intuitions - is far more interventionist and State-centric than that prevailing in the United States. ${ }^{79}$ One reason for this

74. See, e.g., Philippe Malaurie \& Laurent Aynes, Cours de droIt CIVIL: LeS CONTRATS SPECIAUX 21-22 (1989).

75. See, e.g., Pablo Carlos Barbieri, Los contratos en el nuevo Código Civil y Comercial: breve panorama de una reforma necesaria, SISTEMA ARGENTINO DE INFORMACIÓN JURIDICA (Oct. 9 , 2014) (translated by author), http://www.saij.gob.ar/pablo-carlos-barbieri-contratos-nuevo-codigo-civilcomercial-breve-panorama-una-reforma-necesaria-dacf140746-2014-10-09/123456789-0abc-defg647041 fcanirtcod.

76. Beale, supra note 42 , at 521 (noting that it is "certainly true . . that some types of specific contracts which in continental laws may be regulated by legislation are not coherently regulated in English law").

77. See, e.g., A. Brooke Overby, An Institutional Analysis of Consumer Law, 34 VAND. J. TRANSNAT'L L. 1219 (2001) (providing an overview of consumer protection in the United States).

78. For criticisms of state consumer protection acts in the United States, which generally focus on fraud and misrepresentation claims, see, for example, Henry N. Butler \& Jason S. Johnston, Reforming State Consumer Protection Liability: An Economic Approach, 2010 COLUM. BUS. L. REV. 1 (2010).

79. See Jane K. Winn \& Brian H. Bix, Diverging Perspectives on Electronic Contracting in the U.S. and EU, 54 CLEV. ST. L. REV. 175, 190 (2006); Jane K. Winn \& Mark Webber, The Impact of EU Unfair Contract Terms Law on U.S. Business-to-Consumer Internet Merchants, 62 BuS. LAW. 209, 211 (2006) 
apparent gulf is that U.S. regulatory schemes have displayed a clear preference for disclosure mandates or incentive-based regulation, whose ineffectiveness has only recently been the object of serious scholarly criticism. ${ }^{80}$ By contrast, civil law jurisdictions and EU law rely more heavily on "blacklisted" or "graylisted" terms, to the dismay of U.S. law and economics scholars, who have decried their inefficiency to the detriment of consumers. ${ }^{81}$

Usury laws are yet another manifestation of the State's willingness to control contract terms, with common and civil law jurisdictions generally splitting along predictable lines. Although the French Code civil shunned interest rate restrictions, France reintroduced usury ceilings in 1807 and continues to defend them vigorously up to the present time. ${ }^{82}$ Albeit in different forms, interest rate restrictions remain prevalent in various other civil law jurisdictions, such as Italy, Belgium, Spain, Portugal, and Brazil. ${ }^{83}$ As the archetypal common law jurisdiction, England has long avoided strict usury limitations, based on the continued belief that the "state should interfere as little as possible with the consumer's freedom to use his knowledge of the consumer credit market to the best of his ability and according to his judgment of what constitutes his best interests."84 The divide is less clear-cut with respect to the United States, which has a long history of state usury laws, even though they are riddled with exceptions and largely preempted by federal legislation introduced during the deregulation movement. ${ }^{85}$

To be sure, parties may seek to undermine the grip of the State over contract terms by selecting the law of a less interventionist jurisdiction to govern the agreement. Nevertheless, the choice of a foreign law can be costly and is often unavailable. ${ }^{86}$ While both civil and common law jurisdictions

80. On the shortcomings of mandatory disclosure, see OMRI BEN-SHAHAR \& CARL SCHNEIDER, MORE THAN YOU WANTED TO KNOW 4 (2016) (questioning the efficacy of disclosure mandates as a regulatory strategy); Florencia Marotta-Wurgler, Does Contract Disclosure Matter?, 168 J. INSTITUTIONAL \& THEORETICAL ECON. 94 (2012) (finding that increased disclosure has little effect on consumers' readership of contract terms and purchase decisions). For a critique of the incentive-based approach embraced by the Dodd-Frank Act, see Ryan Bubb \& Prasad Krishnamurthy, Regulating Against Bubbles: How Mortgage Regulation Can Keep Main Street and Wall Street Safe-From Themselves, 163 U. PA. L. REV. 1539 (2015).

81. Omri Ben-Shahar, Regulation through Boilerplate: An Apologia, 112 MiCH. L. REV. 883, 893-9 (2014); Oren Bar-Gill \& Omri Ben-Shahar, Regulatory Techniques in Consumer Protection: $A$ Critique of European Consumer Contract Law, 50 COMMON MKT. L. REV. 109, 109-10 (2013) (noting that "[e]ighty-one (!) provisions in the CESL are mandatory").

82. Iain Ramsay, "To Heap Distress upon Distress?": Comparative Reflections on Interest Rate Ceilings, 60 U. TORONTO L.J. 707, 723, 727 (2010).

83. For a survey of EU jurisdictions, see INSTITUT FUR FINANZDIENSTLEISTUNGEN E.V. \& ZENTRUM FÚR EUROPÄISCHE WIRTSCHAFTSFORSCHUNG GMBH, STUDY ON INTEREST RATE RESTRICTIONS IN THE EU: FINAL REPORT FOR THE EU COMMISSION (2010), http://ec.europa.eu/internal_market/finservices-retail/docs/credit/irr_report_en.pdf.

84. See Ramsay, supra note 82, at 730 (quoting CONSUMER CREDIT COMM., CONSUMER CREDIT: REPORT OF THE COMMITTEE, 1971, Cmnd. 4596, 13.9 .1 (UK)) (internal quotation marks omitted).

85. Richard Hynes \& Eric A. Posner, The Law and Economics of Consumer Finance, 4 AM. L. \& ECON. REV. 168, 177 (2002) (arguing that the practical effect of usury laws on credit markets "is likely to be limited").

86. See Mariana Pargendler, Comparative Contract Law and Development: The Missing Link?, 85 GEO. WASH. L. REV. (forthcoming 2018) (manuscript at 8). 
generally recognize and enforce the parties' choice of law, there are still relative differences in the degree of deference afforded to choice of law clauses-not least because the legal traditions also diverge in their willingness to impose mandatory terms imbued with public policy considerations that cannot be opted out of. The U.S. approach to choice of law in consumer contracts turns out to be more liberal than that adopted by the European Union, to the detriment of consumer protection. ${ }^{87}$ Moreover, European courts have refused to enforce choice of law and choice of forum clauses in commercial agreements out of concern that a foreign court would not respect critical mandatory terms. ${ }^{88}$

In the end, the normative desirability of the State's supply of default and mandatory rules remains subject to dispute, which ultimately hinges on one's views about the State's capacity to cure market failures and anticipate parties' needs. At their best, default rules can be powerful mechanisms to reduce transaction costs. The presence of plentiful and balanced statutory default rules may be another reason why contracting parties in civil law jurisdictions can write shorter contracts. ${ }^{89}$ At their worst, however, default and especially mandatory rules prevent the adoption of efficient contract terms.

Either way, there seems to be a clear pattern of greater State intervention (or assistance, if you will) with respect to contract terms in the civil law rather than in the common law. Common law lawyers do not usually feel at ease with the civilian approach, "perhaps because of their antipathy toward the hierarchical ordering by central law-making bureaucracies." ${ }^{.90}$ Common law parties effectively compensate for the absence of State-provided terms through a private supply of standard-form contracts and boilerplates, which offer comparable advantages in terms of network externalities and transaction cost savings. ${ }^{91}$

Whether public or private solutions are superior in this context remains an open question on which reasonable minds disagree. Interestingly, it turns out that scholars from different traditions tend to have opposite normative views on this issue. Continental lawyers continue to favor public (and especially

87. James J. Healy, Consumer Protection Choice of Law: European Lessons for the United States, 19 DUKE J. COMP. \& INT'L L. 535 (2009) (finding that U.S. courts have inconsistently applied public policy considerations to guarantee consumer protections afforded by home state laws).

88. Franco Ferrari, Forum Shopping: A Plea for a Broad and Value-Neutral Definition 31-32 (N.Y.U. Pub. Law \& Legal Theory Research Paper Series, Working Paper No. 14-39, 2013) (describing how the German Supreme Court declined to enforce the choice of the law and forum of Virginia in a commercial agency contract in order to ensure the application of the generous post-termination indemnity rights enjoyed by the agent under German and EU law).

89. Hill \& King, supra note 48, at 912-15; Hein Kotz, The Jurisdiction of Choice: England and Wales or Germany?, 6 EUR. REV. PRIV. L. 1243, 1246-47 (2010).

90. Hein Kotz, Contract Law in Europe and the United States: Legal Unification in the Civil Law and Common Law, 27 TUL. EUR. \& CIV. L. F. 1, 15 (2012).

91. On the economic justifications for the pervasive use of boilerplate in the common law world, see, for example, Robert B. Ahdieh, The Strategy of Boilerplate, 104 MICH. L. REV. 1033 (2006); Kevin E. Davis, The Role of Nonprofits in the Production of Boilerplate, $104 \mathrm{MICH}$. L. REV. 1075 (2006); Marcel Kahan \& Michael Klausner, Standardization and Innovation in Corporate Contracting (Or "The Economics of Boilerplate"), 83 VA. L. REV. 713 (1997). 
legislative) provision of both mandatory and default contract terms. ${ }^{92}$ One civil law scholar has gone so far as to claim that the type of State-supplied default rules found in civil law countries has a distinctive impact on economic development. ${ }^{93}$

Civil law jurisdictions have officially underscored the utility of Statesupplied terms in the "battle of the brochures" triggered in response to England's advertising efforts about the competitive benefits of its legal system. The German pamphlet, for example, mentions the country's "specific statutes that lay down rules for individual types of contracts," as well as the "catch-all provisions that apply in cases where the contractual parties have not agreed otherwise." The result, the pamphlet argues, is that "not only are contracts under German law more concise; they are also more cost-effective and reliable than contractual agreements under English or U.S. law."96 A brochure that advertises the merits of Continental law compared to the common law raises the same point. ${ }^{97}$ Common law lawyers, by contrast, generally lack a similar enthusiasm for the legislation of contract terms, and even the more modest support for the consolidation of default standards through Restatements and codification seems to be fading in recent years. ${ }^{98}$

\section{Interpretation and Policing of Contract Terms}

The more interventionist role of the State in the civil law also sheds light on other fundamental differences in the law of contracts. Take, for instance, the difficult issue of whether exogenous changes in circumstances after the formation of a contract should affect the parties' obligations or the terms of the agreement. While German courts initially resorted to the principle of good faith under $\S 242$ of the Bürgerliches Gesetzbuch (BGB) to adjust contract terms in

92. See Pierre Tercier, Des législateurs innommés, in INNOMINATVERTRÄGE: FESTGABE ZUM 60. GEBURTSTAG VON WALTER R. SCHLUEP 45, 57 (1988) (defending the role of the legislature in the regulation of typical contracts).

93. For a quixotic, if unpersuasive, study supporting this claim, see Raouf Boucekkine et al., Contract Rules in Codes and Statutes: Easing Business Across the Cleavages of Legal Origins, in InSTITUTIONAL COMPETITION BETWEEN COMMON LAW AND CiviL LAW: THEORY AND POLICY 41 (Henrik Schmiegelow \& Michèle Schmiegelow eds., 2014).

94. The term comes from Stefan Vogenauer, Regulatory Competition through Choice of Contract Law and Choice of Forum in Europe: Theory and Evidence, 21 EUR. REV. PRIV. L. 13, 30 (2013). For the U.K. brochure, see supra note 43 and accompanying text.

95. BUNDESNOTARKAMMER [GERMAN CIVIL LAW NOTARIES] ET. AL, LAW MADE IN GERMANY 7 (2012), http://lawmadeingermany,de/Law-Made_in_Germany_EN.pdf.

96. Id.

97. J. M. Baïssus et al., Continental Law, KonTINENTALES Recht (Feb. 7, 2011), www.kontinentalesrecht.de/tl_files/kontinental-base/Broschuere_FR.PDF ("[Civil law] not only contains general provisions applicable to all contracts, but also specific rules for different types of contracts. These rules provide what are deemed to be most equitable solutions to problems that individuals and businesses are likely to encounter in ordinary contracts. They also enable contracts to be written clearly and succinctly, thereby making them less costly and afford [sic] a higher degree of legal certainty. Contrary to common law countries, the parties do not have to create their own rules for each contract; the contract only needs to stipulate clauses on issues on which the parties wish to exclude or supplement the rules of the Code.").

98. For a vigorous critique of existing attempts to complement the common law of contracts with more expansive default rules and standards, see Alan Schwartz \& Robert E. Scott, The Common Law of Contract and the Default Rule Project, 102 VA. L. REV. 1523 (2016). 
view of hyperinflation in the 1920 s, other civil law countries used different doctrines or general clauses to address similar problems: for example, imprévision in France (though historically limited to contracts with the State), ${ }^{99}$ eccessiva onerosità sopravvenuta in Italy, and onerosidade excessiva in Brazil. ${ }^{100}$ Judicial remedies for unforeseen changes in circumstances also exist under the common law, usually under the doctrines of frustration of purpose or impracticability.

The general direction of the common-civil law divergence here is similar to that observed in other areas. Civil law courts are generally more willing than common law courts to rewrite or discharge contracts ex post if the parties did not expressly contemplate this result. In Hans Baade's description of the differences in the application of frustration of purpose and the doctrine of rebus sic stantibus, "the common law rule is, or appears to be, too narrow to accommodate the business world in the present age of random economic catastrophe." 101 At the same time, "[t]he twentieth-century civil law rule developed primarily in Germany ... . seems dangerously open to subjective manipulation." 102

The opinion in Aluminum Company of America (Alcoa) v. Essex Groupperhaps the most prominent instance of a U.S. court rewriting contract terms in view of changed circumstances - is illustrative in this regard. ${ }^{103}$ In finding that the inflation index adopted in the contract produced a windfall for one of the parties (and imposed an alternative index where none was asked for), ${ }^{104}$ Judge Hubert Teitelbaum specifically cited the law of various civil law jurisdictions, such as Germany, Brazil, and Argentina, for their recognition of judicial adjustment to contracts. ${ }^{105}$ The judge noted that although " $[t]$ he time of the Law Merchant is past, and our legal system differs from theirs, . . America has no monopoly on wisdom and may well profit from the experience and learning of other nations." 106 This degree of judicial intervention on contract terms was surprising in the U.S. context and drew considerable criticism, not least because of the consistent declarations by U.S. courts that they would not rewrite the deal that the parties had made. ${ }^{107}$ Although commentators have spent much ink on the Alcoa decision, its controversial ruling was never put

99. While French law has been traditionally reluctant to adjust private contracts in view of changed circumstances, the 2016 reform to the Code civil finally incorporated the doctrine of imprévision as a ground for revision or termination of private agreements. Jan M. Smits \& Caroline Calomme, The Reform of the French Law of Obligations: Les Jeux Sont Faits, 23 MAASTRICHT J. EUR. \& COMP. L. 1040, 1045 (2016).

100. See L.M. Martinez Velencoso, Change of Circumstances, in EUROPEAN PERSPECTIVES ON THE COMMON EUROPEAN SALES LAW 148 (2014) (regarding Italy); LAURA CoRADINI FRANTZ, REVISÃO DOS CONTRATOS 95 (2007) (regarding Brazil). (1983).

101. Hans W. Baade, Comparative Law and the Practitioner, 31 AM. J. COMP. L. 499, 510

102. Id.

103. 499 F. Supp. 53 (W.D. Pa. 1980).

104. Robert Scott \& George Triantis, Anticipating Litigation in Contract Design, 15 Y ALE L.J. 814, 843-44 (2006).

105. Aluminum Co. of Am, 499 F. Supp. at 78 and appendix.

106. Id. at 78 .

107. Stewart Macaulay, An Empirical View of Contract, 1985 WIS. L. REV. 465, 475 (1985). 
into effect, 108 and the case has "virtually faded into obscurity" in terms of judicial impact. ${ }^{109}$

U.S. courts have been similarly reluctant in applying the doctrines of impracticability and frustration of purpose. ${ }^{110}$ The U.S. experience during the financial crisis of 2008 , which was triggered by massive defaults in subprime mortgage contracts due to changed circumstances, confirms this point. Even though reports of harsh terms and practices abounded, ${ }^{111}$ judicial modification of contract terms did not emerge as a favored solution. While the financial crisis has prompted legal scholars in Continental Europe to call for the adjustment of contract terms under existing common law doctrines, ${ }^{112}$ their U.S. counterparts have largely neglected a more interventionist role for contract law in this context. ${ }^{113}$ English law has followed a similarly restrictive approach to judicial modifications during a financial crisis, even when the contracts in question contained general force majeure clauses. ${ }^{114}$

Beyond rewriting, or not, the terms of the agreement to compensate for changed circumstances, courts can also adopt a more or less interventionist approach to contract interpretation. Courts play a stronger role when they are more willing both (i) to consider extrinsic evidence about the negotiation process and (ii) to imply contract terms beyond those spelled out in the written agreement, in order to ascertain, and then to do justice to, the true intention of the parties. Conversely, courts play a weaker role when they refuse either to look beyond the four corners of the written contract or to rewrite the agreement to best reflect the parties' presumptive wishes. In this area as well, the civil law allows for a greater role for the State, while the common law favors a more

108. Id. at 476 (describing how the parties settled the case under unfavorable terms to Alcoa after the federal appellate court conveyed to the parties its skepticism about the lower court's decision).

109. Sheldon W. Halpern, Application of the Doctrine of Commercial Impracticability: Searching for the "Wisdom of Solomon", 135 U. PA. L. REV. 1123, 1127 (1987).

110. Victor P. Goldberg, Contracts, in THE OXFORD HANDBOOK OF CAPITALisM 250, 266 (Dennis C. Mueller ed., 2012) ("Despite the relatively generous language of the Code [on impracticability], courts, with some exceptions, have been unsympathetic to aggrieved parties."); John P. Dawson, Judicial Revision of Frustrated Contracts: The United States, 64 B.U. L. REV. 1, 2 (1984) (describing the "wide divergence" between U.S. and German law as to the judges" power to revise frustrated contracts).

111. See, e.g., Oren Bar-Gill, The Law, Economics and Psychology of Subprime Mortgage Contracts, 94 CORNELL L. REV. 1073 (2009) (describing how the design of subprime mortgage contracts exploited the imperfect rationality of borrowers); MICHAEL W. HUDSON, THE MONSTER: HOW A GANG OF PREDATORY LENDERS AND WALL STREET BANKERS FLEECED AMERICA-AND SPAWNED A GLOBAL CRISIS (2010) (providing a journalistic account of abusive lending practices).

112. See, e.g., Henrik Schmiegelow \& Michele Schmiegelow, Contract Modification as a Rebus Sic Stantibus Solution to the Subprime Crisis, in INSTITUTIONAL COMPETITION BETWEEN COMMON LAW AND CIVIL LAW: THEORY AND POLICY, supra note 93, at 83. For a multi-country comparative volume on this issue, see THE EFFECTS OF FINANCIAL CRISES ON THE BINDING FORCE OF CONTRACTS: RENEGOTIATION, RESCISSION OR REVISION (Başak Başoglu ed., 2016) (confirming the more restrictive approach of common law jurisdictions to contract adjustments).

113. For a notable exception, see George M. Cohen, The Financial Crisis and the Forgotten Law of Contracts, 87 TUL. L. REV. 1 (2012).

114. Horace Yeung \& Flora Yeung, Certainty Over Clemency: English Contract Law in the Face of Financial Crisis, in THE EFFECTS OF FINANCIAL CRISES ON THE BINDING FORCE OF CONTRACTS, supra note 112 , at 288-89, 303 ("As opposed to some civil law jurisdictions, in common law jurisdictions, major market changes are rarely, if ever, the basis of avoidance of a contractual obligation."). 
restrained approach to contract interpretation. ${ }^{115}$ The greater forbearance that characterizes common law courts, especially in England, creates strong incentives for the parties to specify their obligations themselves, even if at the cost of occasionally permitting implausible results that are unlikely to reflect the ultimate will of the parties. ${ }^{116}$ While scholars have argued that English courts often resort to contract interpretation to police the terms of the agreement, ${ }^{117}$ their comparative restraint in meddling with the contract language permits unfair outcomes that would come as a shock to a civilian observer. $^{118}$

The extent to which jurisdictions are willing to subject contract terms to a fairness test-especially where there are imbalances in bargaining power-also varies along the same lines. ${ }^{119}$ German law is famous for imposing a strict

115. See, e.g., Stefan Vogenauer, Interpretation of Contracts: Concluding Comparative Observations, in CONTRACT TERMS 123, 149-50 (Andrew Burrows \& Edwin Peel eds., 2007) (noting that while "there is much less of a fundamental divide between English law and its Civilian counterparts than is frequently assumed ... [t]he most striking difference in the features of contractual interpretation examined in this paper is the readiness to have recourse to prior negotiations and subsequent conduct of the parties"); Gilles Cuniberti, The International Market for Contracts: The Most Attractive Contract Laws, 34 Nw. J. INT'L L. \& BUS. 455, 506-07 (2014) (describing the Swiss law approach to contract interpretation as being more formalist than German law but more contextualist than English law); Kötz, supra note 89, at 1251 (noting that, under English law, "it is primarily for the parties, and only very exceptionally for the court, to determine the content and scope of their agreement"); Chunlin Leonhard, Beyond the Four Corners of a Written Contract: A Global Challenge to U.S. Contract Law, 21 PACE INT'L L. REV. 1, 2 (2009) ("U.S. courts will generally refuse to look beyond the four corners of the written contract."). Still, law and economics scholars have criticized the U.S. courts' approach to commercial agreements as not sufficiently textualist and as too deferential to the contracting parties' choices. See, e.g., Schwartz \& Scott, supra note 66 , at 541.

116. See, e.g., Ulrich Magnus, The Germanic Tradition: Application of Boilerplate Clauses Under German Law, in BOILERPLATE CLAUSES, INTERNATIONAL COMMERCIAL CONTRACTS AND THE APPLICABLE LAW, supra note 26, at 179, 181-82 ("[C]ommon law courts are more reluctant than German courts to fill gaps or even to rewrite parts of the contract."). See also Kotz's description of a 1997 decision by the U.K. House of Lords:

This was a case in which a tenant was entitled to terminate a lease on the third anniversary of the commencement date, and it was agreed that this date was 13 January. The tenant served on the landlord a notice to terminate the lease on 12 January. This was obviously a slip on the part of the tenant, and since there was no reasonable doubt that the landlord was perfectly aware of the fact that there was a slip, a German court would have had no problem in finding the notice valid. Not so the Court of Appeal. It held in a unanimous judgment that the notice was ineffective on the simple ground that ' 12 January' could not possibly mean ' 13 January', that strict compliance with the terms of the lease was of paramount importance in the interest of legal certainty and predictability, and that if the notice were treated as valid a great deal of confusion and unnecessary litigation would follow. The House of Lords allowed the appeal. However, it did so by a bare majority of $3: 2$, and I hope you will allow me to cite this case as an example of the propensity of English commercial lawyers to think that "it is better that the law should be certain than that in every case it should be just."

Kotz, supra note 89, at 1250 (citation omitted).

117. See Catherine Mitchell, Interpreting Commercial Contracts: The Policing Role of Context in English Law, in COMPARATIVE CONTRACT LAW: BRITISH AND AMERICAN PERSPECTIVES, supra note 22 , at 231 .

118. For a recent example, see Arnold v. Britton [2015] UKSC 36. In this case, the U.K. Supreme Court exhibited reluctance to interfere with the clear terms of the contract in the name of "commercial good sense," even if at the cost of "potentially catastrophic financial consequences for the lessees directly concerned." Id. at ๆๆ 77, 80 .

119. See, e.g., Simon Whittaker, The Optional Instrument of European Contract Law and Freedom of Contract, 7 EUR. REV. CONT. L. 371 (2011) (arguing that the greater control of "unfair" contract terms under German law compared to English law reflects a different conception of freedom of contract). This means that "the control of unfair terms does not qualify the party's 'contractual 
fairness test on standardized contract terms, even in business-to-business transactions. ${ }^{120}$ In France, courts have had broad powers to invalidate terms in consumer contracts that are considered abusive, and a recent reform to the Code civil extended this treatment to all contracts of adhesion. ${ }^{121}$ While the U.K. Unfair Contract Terms Act of 1977 also controls standardized terms, it is less strict than its German counterpart. ${ }^{122}$ In the United States, courts may, but rarely do, resort to the doctrine of unconscionability to void unfair contract terms. ${ }^{123}$

It is telling that Williams v. Walker-Thomas Furniture Co, the most famous U.S. case applying the doctrine of unconscionability, concerned the unfairness not of the principal bargain, but of the cross-collateral clause that applied in the event of default. ${ }^{124}$ In other words, Williams was essentially a case about the remedies available for breach of contract - an area where, as we shall see below, U.S. law is far more likely to intervene. ${ }^{125}$ There has been a marked trend in U.S. law to attribute protective and regulatory concerns to other areas of law - to the effect that contract law as conventionally understood has become a "law of leftovers." 26

Finally, it is worth noting that the civil law of contracts contemplates a more robust role of the State not only in supplying and interpreting the terms of the agreement, but also in imposing obligations on the parties before they have entered into a legally binding contract. Another famous distinction in the comparative literature concerns the relative scope of precontractual liability. ${ }^{127}$ Although different doctrinal labels mask a significant degree of functional

autonomy,' it seeks to protect it." Id. at 375 .

120. Gerhard Dannemann, Common Law-Based Contracts Under German Law, in BOILERPLATE ClAUSES, INTERNATIONAL COMMERCIAL CONTRACTS AND THE APPLICABLE LAW, supra note 26 , at 2,76 .

121. Smits \& Calomme, supra note 99 , at 7.

122. Dannemann, supra note 120 , at 76 .

123. See Larry A. DiMatteo \& Bruce Louis Rich, A Consent Theory of Unconscionability: An Empirical Study of Law in Action, 33 FLA. ST. U. L. REV. 1067, 1115 (2006) (finding that reformation is generally rare, and that "it is very difficult for a merchant to succeed in an unconscionability claim"); Anne Fleming, The Rise and Fall of Unconscionability as the "Law of the Poor," 102 GEO. L.J. 1383, 1386 (2014) (claiming that the promise that the unconscionability doctrine could protect low-income borrowers has not materialized).

124. When low-income consumer Williams defaulted on the payment of one household good, Walker-Thomas Furniture sought to enforce the cross-collateral clause to repossess everything Williams had bought in the store in the previous five years. 350 F.2d 445 (D.C. Cir. 1965).

125. See generally E. ALLAN FARNSWORTH, CONTRACTS 841 (1999) ("Compared with the extensive power that contracting parties have to bargain over their substantive contract rights and duties, their power to bargain over their remedial rights is surprisingly limited."); George Triantis, Promissory Autonomy, Imperfect Courts, and the Immorality of the Expectation Damages Default, 45 SUFFOLK U. L. REV. 827 (2012) (criticizing the restrictions under existing law to the parties' determination of damages).

126. Robert W. Gordon \& Morton J. Horwitz, Introduction, in LAW, SOCIETY, AND HISTORY: THEMES IN THE LEGAL SOCIOLOGY AND LEGAL HISTORY OF LAWRENCE M. FRIEDMAN 9 (Robert W. Gordon \& Morton J. Horwitz eds., 2011).

127. See, e.g., Sylviane Colombo, The Present Differences between the Civil Law and Common Law Worlds with Regard to Culpa in Contrahendo, 2 TILBURG FOR. L. REV. 341, 341 (1993) (describing the duty of good faith in precontractual negotiations as a "striking example of the way Continental legal thinking differs from its American counterpart"). 
substitution, ${ }^{128}$ civil law jurisdictions are still more likely to find one party liable for the damages caused to the other during the phase of negotiations. ${ }^{129}$ This in large part hinges on the existence in the civil law-and absence in the common law-of a general duty to bargain in good faith during the precontractual stage. ${ }^{130}$

The idea of precontractual liability in the form of culpa in contrahendo traces back to the work of German law jurist Rudolf von Jhering, ${ }^{131}$ but it was French scholar Raymond Saleilles who first advocated for the imposition of liability for the arbitrary rupture of negotiations in violation of good faith. ${ }^{132}$ The idea gradually took off in other civil law jurisdictions as well. ${ }^{133}$ Throughout the twentieth century, U.S. courts have weakened the requirement of consideration and become more willing to impose liability for promissory estoppel in the absence of an enforceable contract. ${ }^{134}$ Common law scholars and courts, however, have continued to perceive strong versions of precontractual liability as unduly interventionist and even antagonistic to the very "utility of contract as an instrument of self-government."135 Prominent precedents that stand for the availability of precontractual liability for detrimental reliance under U.S. law, such as Hoffman v. Red Owl Stores, ${ }^{136}$ have had little impact on subsequent courts. ${ }^{137}$

\section{B. Contract Remedies}

With respect to substantive contract terms, the civil/common law comparison shows a reasonably clear pattern, with civil law courts demonstrating greater willingness to intervene in the supply of contractual

128. See, e.g., Friedrich Kessler \& Edith Fine, Culpa in Contrahendo, Bargaining in Good Faith, and Freedom of Contract: A Comparative Stucty, 77 HARV. L. REV. 401, 448 (1964) (arguing that despite the absence of the same doctrinal labels, in substantive terms, "notions of good faith and culpa in contrahendo have not been confined to civil law countries").

129. Jonathan Cardenas, Deal Jumping in Cross-Border Merger \& Acquisition Negotiations: A Comparative Analysis of Pre-Contractual Liability Under French, German, United Kingdom and United States Law, 9 N.Y.U. J. L. \& Bus. 941, 945 (2013); Colombo, supra note 127, at 369; E. Allan Farnsworth, Precontractual Liability and Preliminary Agreements: Fair Dealing and Failed Negotiations, 87 COLUM. L. REV. 217, 239 (1987).

130. Colombo, supra note 127 , at 345 .

131. Rudolf von Jhering, Culpa in Contrahendo oder Schadensersatz bei nichtigen oder nicht zur Perfection gelangten Vertragen, in 4 JAHRBUCCHER FÜR DIE DOGMATIK DES HEUTIGEN ROMISCHEN UND DEUTSCHEN PRIVATRECHTS 1 (Carl Friedrich von Gerber \& Rudolf von Jhering eds., 1861).

132. Raymond Saleilles, De la responsabilité précontractuelle, 6 REV. TRIMESTRIELLE DROIT CIVIL 697 (1907)

133. Farnsworth, supra note 129 , at 239.

134. See, e.g., Cosgrove v. Bartolotta, 150 F.3d 729 (7th Cir. 1998) (upholding the jury's finding of liability for promissory estoppel); Lawrence Cunningham, Cardozo and Posner: A Study in Contracts, 36 WM. \& MARY L. REV. 1379, 1404-05 (1995).

135. Kessler \& Fine, supra note 128 , at 412.

136. 26 Wis. 2 d 683 (1965).

137. Farnsworth, supra note 129, at 237 ("[D]uring the two decades since Red Owl was handed down, its influence has been more marked in the law reviews than in the law reports."); Alan Schwartz \& Robert E. Scott, Precontractual Liability and Preliminary Agreements, 120 HARV. L. REV. 661, 668 (2007) (noting that the conventional wisdom that U.S. law recognizes precontractual liability for reliance investments is flawed, since "[c]ourts actually make some form of agreement a necessary condition to a promisee's recovery."). 
provisions by complementing or even overriding the parties' choice of terms. This section will show that, interestingly, the same pattern of greater State involvement in the civil law is visible with respect to contract remedies. Once a contract passes muster under the civil law's more stringent control of contract terms, the State is also more aggressive in enforcing the agreement, both by awarding stronger contract remedies for breach and by restricting the availability of discharge in bankruptcy. While the common law's lesser scrutiny of contract terms would suggest that it is more respectful of freedom of contract, the common law's treatment of contract remedies makes State support to contract enforcement in this tradition look far more subdued.

Before proceeding, however, it is worth pausing to acknowledge that the existence and measurement of State intervention in contract remedies critically depend on the baseline adopted. The baseline used here is one of no State involvement in the enforcement of promises. This means that, in a system where there is no State intervention, contracts cannot be legally enforced. In this view, the State plays a lesser role when it offers no remedies (or only weak remedies) for breach of contract, and a stronger role when it backs contractual agreements with judicial enforcement of more severe consequences. The contributions of legal realists and institutional economists, as well as the tradition of U.S. constitutional doctrine, support this choice of baseline. ${ }^{138}$

However, other starting points are possible. One may take the position that government intervention is minimized when the State strictly enforces the agreement in accordance with its terms. In this view, the common law treatment of remedies implies greater, and the civil law lower, levels of intervention. Alternatively, for those who understand that corrective justice requires protection of the expectation interest, the State may be viewed as interfering when it enforces both penalty clauses and contractual limitations of remedies. ${ }^{139}$ While these different baselines lead to disparate conclusions about the degree and direction of State intervention, they do not otherwise affect this Article's core conclusion. It remains the case that the State plays different but complementary roles in its treatment of contract terms and contract remedies in

138. For examples of the conceptualization of contract enforcement as State power by realist and critical scholars, see KERRY RITTICH, RECHARACTERIZING RESTRUCTURING: LAW, DISTRIBUTION, AND GENDER IN MARKET REFORM 134 (2002) ("Contract, in essence, is a promise that courts are prepared to enforce; far from private, the inevitable decisions concerning enforcement make contract very much a public venture."); Morris R. Cohen, The Basis of Contract, 46 HARV. L. REV. 553, 586 (1933) ("The law of contract, then, through judges, sheriffs, or marshals puts the sovereign power of the state at the disposal of one party to be exercised over the other party. . . [T] he ability to use the forces of the state to collect damages is still a real sovereign power and the one against whom it can be exercised is in that respect literally a subject."). The analysis of institutional economists also proceeds from a baseline of no State enforcement of contracts. See Simeon Djankov, Edward L. Glaeser, Rafael La Porta, Florencio Lopez-de-Silane \& Andrei Shleifer, The New Comparative Economics, 31 J. CoMP. ECON. 595, 598 (2003) (arguing that "the four common strategies of such [social] control [of business], namely private orderings, private litigation, regulation, and state ownership, can be viewed as points on the institutional possibility frontier, ranked in terms of increasing state powers"). On U.S. constitutional doctrine, see infra notes 189 and 242-247 and accompanying text.

139. For a defense of expectation damages in view of corrective justice, see Ernest $J$. Weinrib, Punishment and Disgorgement as Contract Remedies, 78 CHI.-KENT L. REV. 55 (2003). The analysis developed here takes a different baseline, which is that any enforcement measure by the State beyond zero qualifies as State action. 
the civil and common law traditions. In all instances, as we will see below, the civil law favors stronger, and the common law weaker, remedies for breach of contract.

\section{Specific Performance}

A central area of civil-common law divergence in the law of contracts concerns the availability of specific performance. At least in principle, civil law jurisdictions regard specific performance as the primary remedy for breach of contract. By contrast, the main consequence of a breach of contract in the common law is the obligation to pay damages. ${ }^{140}$ In the famous words of Oliver Wendell Holmes, "[t] he duty to keep a contract at common law means a prediction that you must pay damages if you do not keep it, . . . and nothing else." 141 Specific performance, an equitable remedy, is still exceptional in the common law of contracts, available only when an award for damages is not "adequate" and, even then, at the court's discretion. ${ }^{142}$

As in other areas, scholars have cast doubt on the extent and relevance of this divergence. First, the availability of specific performance is not uniform across civil law jurisdictions, but rather varies from country to country, and different exceptions may apply. ${ }^{143}$ Second, specific performance may not be used with significant frequency in civil law practice, even when it is formally available "on the books." 144 Third, common law courts have been increasingly liberal in granting requests for specific performance, suggesting further convergence between both traditions. ${ }^{145}$ Nevertheless, conceptual and practical differences persist. ${ }^{146}$

Whether the common law's hesitancy to embrace specific performance of contracts is economically and morally sound has been a matter of longstanding

140. Rudolf B. Schlesinger, hans W. BaAde, Peter E. Herzog \& Edward M. Wise, COMPARATIVE LAW 739 (6th ed. 1998) ("[T]he civilians' recognition of the obligee's right to specific performance (so long as such performance is not shown to be actually impossible) stands in marked contrast to the common law's preference for non-specific remedies."); JAN M. SMITS, CONTRACT LAW: A COMPARATIVE INTRODUCTION 11 (2014).

141. Oliver Wendell Holmes, The Path of the Law, 10 HARV. L. REV. 457, 462 (1897).

142. RESTATEMENT (SECOND) OF CONTRACTS $\$ \$ 357,359$ (AM. LAW INST. 1981); see also U.C.C. $\$ 2-716$ (1) (AM. LAW. INST. \& UNIF. LAW COMM'N 1977) ("Specific performance may be decreed where the goods are unique or in other proper circumstances.").

143. For an overview of key distinctions, see, for example, Treitel, supra note 5 , $§ 16-7$ to 16 39; John P. Dawson, Specific Performance in France and Germamy, 57 MICH. L. REV, 495 (1959); Henrik Lando \& Caspar Rose, On the Enforcement of Specific Performance in Civil Law Countries, 24 INT'L REV. L. \& ECON. 473 (2004)

144. ZWEIGERT \& KOTZ, supra note 4, at 484 (arguing that, in Germany, specific performance "does not in practice have anything like the significance originally attached to it"); Lando \& Rose, supra note 143, at 486 ("The remedy is available but rarely sought in Germany and France, and has been (virtually) abolished as a remedy for production contracts in Denmark.").

145. See, e.g., FARNSWORTH, supra note 135125, at 769 ("[T] favor of the extension of specific relief at the expense of the traditional primacy of damages."); DOUGLAS LAYCOCK, THE DEATH OF THE IRREPARABLE INJURY RULE (1991) (showing that the availability of specific performance in practice may not be restricted by the irreparable injury rule).

146. See, e.g., Solène Rowan, Remedies for Breach of Contract: A Comparative ANALYSIS OF THE PROTECTION OF PERFORMANCE 20 (2012) (arguing that proponents of convergence "misapprehend the degree and complexity of the differences between specific remedies in England and France, which, on close analysis, are both theoretical and practical"). 
and continued dispute. ${ }^{147}$ On the one hand, the first generation of law and economics scholarship formulated the famous theory of "efficient breach" to justify the common law rule. ${ }^{148}$ According to this theory, in permitting a breach of contract, but requiring the payment of expectation damages to the aggrieved party, the common law system effectively permits the violation of contractual promises. This may well be efficient, however, if, through the payment of damages, the promisee is put in the same position he or she would have been had the contract been performed. Despite the prominence achieved by the efficient breach theory, a large literature has challenged its soundness, arguing that the availability of specific performance can lead to results that are more efficient as well as more consistent with moral intuitions. ${ }^{149}$

While the theoretical debate remains unsettled, commercial practice reveals that contracting parties often favor specific performance with respect to certain types of agreements and obligations. An empirical study by Theodore Eisenberg and Geoffrey Miller found that over fifty-three percent of merger agreements and over forty-five percent of asset sale agreements in the United States contained provisions opting for specific performance in the event of a breach. ${ }^{150}$ However, in a clear constraint on freedom of contract, contracting parties in common law jurisdictions have no assurance that their option for specific performance will prevail in the courtroom. Specific performance clauses are generally influential on, but not dispositive of, the court's decision, which remains fully discretionary. ${ }^{151}$

Regardless of whether expectation damages or specific performance is the most efficient default rule, the common law's reluctance to grant specific performance as a matter of right when the parties have so chosen is puzzlingespecially given the tradition's supposedly great deference to party autonomy.

147. See Gregory Klass, Efficient Breach, in THE PHLOSOPHICAL FoUNDATIONS OF CONTRACT LAw 362, 362 (Gregory Klass, George Letsas \& Prince Saprai eds., 2015) ("The most widely known, and widely criticized, economic claim about contract law is the theory of efficient breach.").

148. The theory was popularized by Richard Posner in his seminal ECONOMIC ANALYSIS OF LAW (1973), a work fundamentally devoted to demonstrating the efficiency of the common law. For a more recent defense of the common law regime disfavoring specific performance under a different conceptualization, see Daniel Markovits \& Alan Schwartz, The Myth of Efficient Breach: New Defenses of the Expectation Interest, 97 VA. L. REV. 1939 (2011) (advancing the "dual performance hypothesis," according to which the payment of damages in lieu of performance should not be interpreted as constituting a breach).

149. See, e.g., Richard R.W. Brooks, The Efficient Performance Hypothesis, 116 YALE L.J. 568 (2006); Daniel Friedmann, The Efficient Breach Fallacy, 18 J. LEGAL STUD. 1 (1989); Alan Schwartz, The Case for Specific Performance, 89 YALE L.J. 271 (1979); Seana Shiffrin, Could Breach of Contract Be Immoral?, 107 MiCH. L. REV. 1551, 1565-66 (2009); Thomas S. Ulen, The Efficiency of Specific Performance: Toward a Unified Theory of Contract Remedies, 83 MICH. L. REV. 341 (1984).

150. Theodore Eisenberg \& Geoffrey P. Miller, Damages Versus Specific Performance: Lessons from Commercial Contracts, 12 J. EMP. L. STUD. 29, 32 (2015).

151. See Stokes v. Moore, 77 So.2d 331, 335 (Ala. 1955) (explaining that the parties' agreement on the issuance of equitable relief is not binding on the court, but "the provision for an injunction is important in its influence upon an exercise of the discretionary power of the court to grant a temporary injunction"); see also Ash Park, LLC v. Alexander \& Bishop, Ltd., 783 N.W.2d 294, 303 (Wis. 2010) ("[W] hen a contract specifies remedies available for breach of contract, the intention of the parties generally governs."). State courts have differed in their deference to contract clauses providing for specific performance, with. Delaware courts appearing to be especially sympathetic to their enforcement. See, e.g., Gildor v. Optical Solutions, Inc., No. 1416-N, 2006 WL4782348WL 4782348, at *12. (Del. Ch. June 5, 2006). 
An additional difficulty is that, contrary to the central assumption in the efficient breach theory, real-life awards for expectation damages only rarely, if ever, fully compensate the harm suffered by the disappointed promisee. ${ }^{152}$ In fact, once the applicable doctrines for the measurement of damages are taken into account, the contrast with the civil law treatment of contract remedies becomes even sharper: not only is specific performance the norm, but damage awards, at least in theory, could be more generous in certain civil law jurisdictions. ${ }^{153}$

The appreciation of the far greater role of the State required for specific performance, however, helps shed light on the puzzle. Specific performance is far more coercive than a mere award for damages. In the common law tradition, in particular, a failure to comply with court orders for specific performance is punishable as contempt of court, leading to fines, imprisonment, or both. ${ }^{154}$ So understood, specific performance is "very intrusive and highly coercive." 155 Alan Farnsworth makes the point that, beyond factors relating to historical path dependence, "[a] more rational basis [for U.S. courts' reluctance to grant specific relief] can be found in the severity of the sanctions available for enforcement of equitable orders."156

Indeed, the critical differences in the devices used to implement specific performance in common and civil law jurisdictions have been largely overlooked. Common law jurisdictions typically lack a mechanism similar to the French astreintes to encourage specific performance. ${ }^{157}$ Originating in French judicial practice and later embraced by other civil law jurisdictions, the astreintes are periodical fines (applying, say, for each day of non-performance) that the judge imposes with the purpose of forcing the promisor to perform.

152. See, e.g., Melvin A. Eisenberg, Actual and Virtual Specific Performance, the Theory of Efficient Breach, and the Indifference Principle in Contract Law, 93 CAL. L. REV. 975 (2005). Eisenberg attributes the undercompensatory nature of expectation damages to a number of doctrinal and institutional features, including (i) the use of market price (rather than buyer's valuation) to assess the measure of damages, (ii) the difficulty in proving lost profits with reasonable certainty, (iii) foreseeability limitations to expectation damages under the classic 1854 English Exchequer case Hadley v. Baxendale, and (iv) the costs of dispute settlement, including insolvency risk. Id. at 989-97; see also Steven Shavell, Is Breach of Contract Immoral?, 56 EMORY L.J. 439, 451 (2006) ("[T]he expectation measure as it is actually applied tends not to be fully compensatory and may leave the victim of a breach substantially worse off than he would have been had there been performance.").

153. See, e.g., Ronald J. Scalise Jr., Why No "Efficient Breach" in the Civil Law?: A Comparative Assessment of the Doctrine of Efficient Breach of Contract, 55 AM. J. COMP. L. 721, 74344, 763 (2007) (attributing the "broader conception of damages" in French law to, among other things, a much weaker requirement of foreseeability); Torgans \& Bushaw, supra note 53, at 66 (noting the absence of a foreseeability limitation under Latvian law). Whether such doctrines translate into higher damage awards is questionable, however. See John Y. Gotanda, Damages in Lieu of Performance Because of Breach of Contract (Villanova Univ. Sch. of Law, Pub. Law \& Legal Theory Working Paper No. 2006-8, 2006), http://papers.ssrn.com/sol3/papers.cfm?abstract id=917424 (arguing that "lost profits are more difficult to obtain in civil law countries because many of these countries impose a high standard of proof for their recovery").

154. GREgory Klass, CONTRACT LAW IN THE UNITED STATES 211 (2012).

155. Eisenberg, supra note 152 , at 1049 . Eisenberg also notes that "[ $t]$ he prospect of jailing or fining one actor to enhance another actor's private gain is inharmonious with social norms concerning the appropriate use of the state's monopoly on force." Id. at 1020.

156. FARNSWORTH, supra note 125 , at 769 .

157. KLASS, supra note 154, at 211 ("There is no equivalent in U.S. law to astreinte, which is available in some civil law jurisdictions."). 
Unlike the fines that common law judges may impose in cases of contempt of court, the amounts paid as astreintes revert to the promisee, above and beyond any compensatory damages due in view of the harm suffered. However, if the total amount ordered as astreintes also appears excessive ex post, the judge then also has the power to equitably reduce it. ${ }^{158}$

Scholars have suggested that the existence of such milder mechanisms to coerce contractual performance could help explain the comparative favor enjoyed by specific performance in civil law countries. ${ }^{159}$ Yet causation could run in the opposite direction: the greater availability of specific performance in the civil law tradition may have encouraged the use of more efficient methods of enforcement. In any case, existing differences in the administration of specific performance are unlikely to capture the entire story. The common law has also resisted strong contractual remedies even when no criminal sanctions are involved, as we will see from its treatment of penalty clauses, to which I now turn.

\section{Penalty Clauses}

The common law's reluctance to provide robust remedies for breach of contract is not limited to specific performance, which, as we have seen, implicates a strong form of State coercion through criminal law. ${ }^{160}$ The same restrictive tendency exists when it comes to the stipulation of damages by the parties themselves. In marked contrast to the civil law, the common law denies enforcement of so-called "penalty clauses." ${ }^{\text {"161 }}$ Penalty clauses are contractual provisions that aim to punish (and therefore deter) breaches of contract by providing for the payment of a sum which exceeds the amount that would be strictly necessary to compensate the promisee for non-performance.

The common law of contracts draws a key distinction between liquidated damages clauses, which are enforceable, and penalty clauses, which are not. Although there are subtle differences among the law of different

158. On the evolution of the astreintes in French law, see M. P. Michell, Imperium by the Back Door: The Astreinte and the Enforcement of Contractual Obligations in France, $51 \mathrm{U}$. TORONTO FAC. L. REV. 250 (1993).

159. John Dawson has raised this possibility: "The interesting question is whether we, like the French, have become prisoners of our own system-or, more accurately, whether we have become confused by our lack of system. Would our courts be more willing to grant specific performance if a sharp line were drawn and firmly maintained between civil and criminal contempt- between execution process for the benefit of the litigant and punishment for attack on judicial authority? Why must every equity order, except some decrees establishing simple money debts, be thought of as carrying implicitly the threat of arrest, money fine, sequestration - the whole panoply of coercive devices that our equity courts draw on at their discretion?" Dawson, supra note 143, at 537-38.

160. Yet the United States, a common law jurisdiction, stands out for the harsh sanctions it is willing to impose on criminal defendants. See BERNARD E. HARCOURT, THE ILLUSION OF FREE MARKETS: PUNISHMENT AND THE MYTH OF NATURAL ORDER (2011); Holger Spamann, The U.S. Crime Puzzle: A Comparative Perspective on U.S. Crime and Punishment, 18 AM. L. \& ECON. REv. 33, 34 (2016) (finding that the United States is a clear outlier for its high incarceration rates).

161. See Aristides N. Hatzis, Having the Cake and Eating It Too: Efficient Penalty Clauses in Common and Civil Contract Law, 22 INT'L REV. L. \& ECON. 381, 381 (2003) (citing penalty clauses as "one of the areas where there is a marked difference between Civil and Common contract law"). 
jurisdictions, ${ }^{162}$ the qualification of a clause as a valid liquidated damages provision generally hinges on whether the amount in question "is reasonable in the light of the anticipated or actual loss caused by the breach and the difficulties of proof of loss." 163 By contrast, "[a] term fixing unreasonably large liquidated damages is unenforceable on grounds of public policy as a penalty."164

This broad ban on penalty clauses has no parallel in the civil law tradition. Typical civil codes, in fact, expressly recognize and regulate penalty clauses. ${ }^{165}$ This does not mean that freedom of contract with respect to penalty clauses is absolute in the civil law. Most jurisdictions today explicitly -and increasingly - provide for various limitations, including the ability of the judge to reduce penalty amounts that are manifestly excessive. ${ }^{166}$ Although the German Commercial Code expressly excludes the reduction of penalty clauses stipulated between merchants, ${ }^{167}$ a recent Supreme Court decision employed the general standard of good faith under $\S 242$ of the BGB to reduce an extreme contractual penalty exceeding 840 times the price of the merchandise sold in violation of the agreement. ${ }^{168}$

Nevertheless, the mere fact that a given sum exceeds a reasonable estimate of actual damages does not per se constitute sufficient grounds for judicial modification of penalty clauses in the civil law. Their punitive character has been, and continues to be, an integral part of the concept. On the

162. A very recent decision by the U.K. Supreme Court has significantly watered down the traditional prohibition against penalties by holding that "[t]he true test is whether the impugned provision is a secondary obligation which imposes a detriment on the contract-breaker out of all proportion to any legitimate interest of the innocent party in the enforcement of the primary obligation." Consequently, a penalty clause may be valid even if it is not a pre-estimate of loss. Cavendish Square Holding BV v. Talal El Makdessi [2015] UKSC 67, [32], [2016] AC 1172.

163. RESTATEMENT (SECOND) OF CONTRACTS \& 356(1) (AM. LAW INST. 1981); see also U.C.C. \$ 2-718(1) (AM. LAW INST. \& UNIF. LAW COMM'N 1977). ("Damages for breach by either party may be liquidated in the agreement but only at an amount which is reasonable in the light of the anticipated or actual harm caused by the breach, the difficulties of proof of loss, and the inconvenience or nonfeasibility of otherwise obtaining an adequate remedy. A term fixing unreasonably large liquidated damages is void as a penalty.").

164. RESTATEMENT (SECOND) OF CONTRACTS $§ 356(1)$ (AM. LAW INST. 1981).

165. Codigo Civil [C.C.] [CIVIL Code], arts. 408-16 (Braz.); Code Civil [C. CIV.] [CivIL CODE], arts. 1226-33 (Fr.); BÜRGERLICHES GESETZBUCH [BGB] [CIVIL CODE], \$§ 339-45, translation at http://www.gesetze-im-internet.de/englisch_bgb/englisch_bgb.html\#p1233 (Ger.).

166. ReINHARD ZimMERMAN, THE LAW OF OBLigations: Roman Foundations of THE CIVILIAN TRADITION 107 (3d ed. 1996) ("Continental codifications generally recognize the validity of conventional penalties, subject, however, to judicial discretion to reduce the amount."); see e.g., Código Civil [C.C.] [Civil Code], art. 413 (Braz.); Code CIVIL [C. CIV.] [CIVIL CoDE], art. 1152 (Fr.)1152; BÜRGERLICHES GESETZBUCH [BGB] [CIVIL CODE] \& 343, translation at http://www.gesetzeim-internet.de/englisch_bgb/englisch_bgb.html\#p1233 (Ger.).

167. HaNDELSGESETZBuCH [HGB] [COMMERCIAL CODE] $\S 348$. (Ger.).

168. See Bundesgerichtshof [BGH] [Federal Court of Justice] July 17, 2008, NEUE JURISTISCHE WOCHENSCHRIFT [NJW] 1882, 2009 (Ger.), as discussed in Florian Faust, Contractual Penalties in German Law, 23 EUR. REV. PRIV. L. 285, 294 (2015). The case concerned an agreement that imposed the payment of 7,500 euros for every individual violation of the contractually assumed obligation not to sell or produce a certain type of children's pillow, which traded at nine euros each. The aggrieved party then claimed an aggregate amount exceeding $53,000,000$ euros for the 7,000 pillows sold in breach of the agreement, but the court ultimately reduced the penalty to 200,000 euros. Id. This example seems to contradict the intuition of some law and economics scholars that contractual penalties are inefficient and therefore business contracts will never provide for them. 
contrary, commentators agree that, even after the eventual reduction of an exorbitant clause, the amount due should exceed actual damages. ${ }^{169}$ Some civil law jurisdictions even permit the parties to collect the contractual penalty in addition to actual compensatory damages if the agreement so provides. ${ }^{170}$

As an exception to the principle of freedom of contract, ${ }^{171}$ the ban on penalty clauses in the common law is controversial, to put it mildly. Like the absence of specific performance, the theory of efficient breach has also served to explain the common law's hostility to contractual penalties. ${ }^{172}$ However, strong critiques to the common law rule have proliferated on this point, possibly even more forcefully than with respect to specific performance. Scholars have justified the efficiency of contract penalties in terms of offering full compensation to promisees with idiosyncratic valuations, ${ }^{173}$ permitting new entrants in the market to signal their ability to perform, ${ }^{174}$ deterring breaches that are difficult to detect, ${ }^{175}$ enabling the parties to bargain for embedded options that serve an insurance function, ${ }^{176}$ and inducing efficient relationspecific investment. ${ }^{177}$

Although commentators have called for the abandonment of the prohibition on penalties, the doctrine has proved resilient. One way to make sense of this is by underscoring the more significant role of State action and coercion implied by penalty clauses - a point similar to that raised above in connection with the analysis of specific performance. However, meaningful differences exist between both mechanisms. First, penalty clauses are no more than overcompensatory damage awards, and, unlike specific performance, do not entail criminal penalties. Second, while specific performance may place significant administrative burdens on the judicial system, penalty clauses

169. SCHLESINGER ET AL., supra note 140, at 747 (" [I]f the obligee recovered no more than such [actual] damages, then the penalty itself-as distinguished from damages-would be wiped out and not merely "reduced.").

170. RowAN, supra note 146, at 198 (describing French judicial decisions on this topic, and arguing that "[t]he contrast with English law could not be more marked").

171. See, e.g., Charles J. Goetz \& Robert E. Scott, Liquidated Damages, Penalties and the Just Compensation Principle: Some Notes on an Enforcement Model and a Theory of Efficient Breach, 77 COLUM. L. REV. 554, 555 (1977) ("The implications of the penalty doctrine are anomalous in terms of the theoretical underpinnings of modern contract law.").

172. See, e.g., RICHARD POSNER, ECONOMIC ANALYSIS OF LAW 55-60 (1973). For another justification of the rule, see Kenneth W. Clarkson, Roger Leroy Miller \& Timothy J. Muris, Liquidated Damages v. Penalties: Sense or Nonsense?, 1978 WIS. L. REV. 351.

173. Goetz \& Scott, supra note 171, at 594 (arguing that the ban on penalty promises leads to inefficient results both by denying true compensation to promisees with idiosyncratic valuations and by requiring judicial review of liquidated damages clauses).

174. Even Richard Posner came to recognize the signaling function of penalty clauses, which would be especially useful by entrants who lack a reputation in the market. RICHARD POSNER, ECONOMIC ANALYSIS OF LAW 93-94 (2d ed. 1977).

175. Aaron S. Edlin \& Benjamin E. Hermalin, Contract Renegotiation and Options in Agency Problems, 16 J.L. ECON. \& ORG. 395, 404-09 (2000).

176. Robert E. Scott \& George G. Triantis, Embedded Options and the Case Against Compensation in Contract Law, 104 COLUM. L. REV. 1428 (2004); George Triantis, The Evolution of Contract Remedies (And Why Do Contracts Professors Teach Remedies First?), 60 U. TORONTO L. J. 643,657 (2010) (calling the penalty rule an "unjustifiable instance of price regulation that inhibits innovation").

177. Aaron Edlin \& Alan Schwartz, Optimal Penalties in Contracts, 78 CHI.-KENT L. REV. 33, 43-52 (2003) (reviewing the literature on the need to ensure efficient investment). 
arguably save courts from the trouble of determining the level of actual damages - an often-difficult task. ${ }^{178}$

Yet penalty clauses still entail the State's willingness to punish breaches of contract. While these clauses are a product of private design, their enforcement depends on the involvement of the State apparatus. From this perspective, the stronger the contract remedy, the more intrusive or oppressive the State action in coercing enforcement will appear to be. ${ }^{179}$ Conversely, the absence of strong mechanisms of State enforcement-leading to weaker contracts that do not always provide an effective remedy to the promisee in the event of a breach - may stimulate the development of less costly extralegal modes of enforcement. ${ }^{180}$

Consistent with this view, the common law's resistance to penalty clauses does not extend to provisions aimed at limiting the scope of contractual liability for damages - that is, by providing for the payment of a sum that is lower than the actual damages. The common law imposes no general limitations to liquidated damages clauses that clearly undercompensate the obligee in the event of a breach. ${ }^{181}$ In the civil law, we see the opposite pattern: most jurisdictions tend to subject limitation of liability clauses to considerable scrutiny, at least comparable to (and possibly even greater than) that applicable to penalty clauses. ${ }^{182}$

178. Justin Sweet, Liquidated Damages in California, 60 CAL. L. REV. 84, 145 (1972) (arguing that more certain enforcement of liquidated damages clauses should, among other things, "relieve the already overburdened courts of the frustrating and difficult process of determining the amount of damages for contract breach"). But see Guido Calabresi \& Douglas Melamed, Property Rules, Liability Rules and Inalienability: One View of the Cathedral, 85 HARV. L. REV. 1089, 1092 (1972) (arguing that property rules - of which specific performance is arguably one example-require the least amount of State intervention in the sense that "once the original entitlement is decided upon, the state does not try to decide its value").

179. Penalty clauses and specific performance may be associated with a greater role of the State in a different way. Paul Rubin has argued that contracts backed by these mechanisms are less likely to be self-enforcing. As a result, the availability of these remedies tends to encourage the use of courts, which are subsidized by society. Paul H. Rubin, Unenforceable Contracts: Penalty Clauses and Specific Performance, 10 J. LEGAL STUD. 237 (1981).

180. See, e.g., Marc Flandreau \& Gabriel Geisler Mesevage, The Separation of Information and Lending and the Rise of Rating Agencies in the USA (1841-1907), 62 SCANDINAVIAN ECON. HIST. REV. 213 (2014) (attributing the rise of rating agencies in the United States to deficiencies in legal enforcement due to protective bankruptcy laws and weak creditor rights).

181. See, e.g., Clarkson et al., supra note 172, at 37; Edlin \& Schwartz, supra note 177, at 35 (reporting their curjosity that "courts do not protect the expectation interest against all contractual encroachments: courts permit parties to underliquidate damages"); Mattei, supra note 5, at 433. Like any other contract clause, limitations of damages could be deemed unconscionable and therefore invalid, though findings of unconscionability are rare. See, e.g., Official Comment to subsection 1 to U.C.C. § 2718 (AM. LAW INST. \& UNIF. LAW COMM"N 1977) ("A term fixing unreasonably large liquidated damages is expressly made void as a penalty. An unreasonably small amount would be subject to similar criticism and might be stricken under the section on unconscionable contracts or clauses." (emphasis added)); Scott \& Triantis, supra note 176, at 1435 (confirming in their analysis of reported cases that "the incidence with which courts strike down penalties far exceeds their rejection of undercompensatory damages provisions")

182. Since the 1975 reform enabling judicial control of penalty clauses, French courts may also increase liquidated damages provisions that are "ridiculously small." SCHLESINGER ET AL., supra note 140 , at 757 . The willingness of the Cour de cassation to invalidate limitations of liability has oscillated over time. In Germany, judicial interpretation of sections 305, 307 and 309 of the BGB has led commentators to note that German law "effectively leave[s] one with no room to draft a standard liability clause that effectively limits one's client's liability were it really matters." Julian Hoeppner, On 
To be sure, the reduction or suppression of contract remedies can also constitute a source of harshness in contractual relations. Indeed, the withdrawal of effective contract remedies from aggrieved consumers - through disclaimers of liability and, most importantly, binding arbitration clauses-is one of the most controversial aspects of contemporary contract law in the United States. ${ }^{183}$ Contract clauses purporting to bind consumers to arbitration are "graylisted" under EU law and prohibited in certain civil law jurisdictions. ${ }^{184}$ In this respect alone, the State's apparently "hands-off" approach to remedies in the United States, which includes the abdication of its own jurisdiction to enforce them, does not necessarily offset the harshness of contract terms, but rather may reinforce it.

Interestingly, more interventionist jurisdictions tend to support stronger remedies for breach of contract. It is striking that socialist countries-which did not otherwise place much value on freedom of contract-not only recognized a non-waivable right to specific performance as the primary contract remedy, ${ }^{185}$ but also employed and enforced penalty clauses with gusto. ${ }^{186}$ In fact, penalty clauses were mandatory under socialist law, and were invariably included in contracts among State-owned enterprises. ${ }^{187}$

In sum, the civil law seems to favor strong, and the common law seems to favor weak, contract remedies. It is telling that the common law appears to be more creditor-friendly than the civil law precisely with respect to those remedies that do not require judicial intervention. When it comes to secured transactions, common law jurisdictions are more likely to permit creditors to strictly foreclose or privately sell the collateral in the event of default. ${ }^{188}$ This is

Liability and Liability Clauses Under German Law, GERMAN IT L. BLOG (June 12, 2012), http://germanitlaw.com/?p=575.

183. For a critique of this approach, see Overby, supra note 77 , at 1277 (describing the enforceability of arbitration in consumer contracts as "perhaps one of the most important issues concerning access to justice today"); Amalia D. Kessler, Stuck in Arbitration, N.Y. TIMES (Mar. 6, 2012), http://www.nytimes.com/2012/03/07/opinion/stuck-in-arbitration.html. But see Omri BenShahar, One-Way Contracts: Consumer Protection Without Law, 6 EUR. REV. CoNT. L. 221 (2010) (arguing that one-sided contracts that bind businesses, but not consumers, can be efficient and potentially improve consumer well-being).

184. See, e.g., Overby, supra note 77, at 1281; CódIGo DE ProteÇÃo E DEFESA DO CONSUMIDOR [C.D.C.] [CONSUMER PROTECTION CODE], art. 51(VII) (Braz.).

185. Gyula Eorsi, Contractual Remedies in Socialist Legal Systems, in 7 INTERNATIONAL ENCYCLOPEDIA OF COMPARATIVE LAW: CONTRACTS IN GENERAL, supra note 3, §§ 16-192 (describing specific performance as "the most conspicuous and characteristic feature of the system of contractual remedies available in Socialist legal systems," given that "the present system of planning rarely permits the existence of a market where damages received may be utilized for purchase of substitutes"); Bernhard Grossfeld, Money Sanctions for Breach of Contract in a Communist Economy, 72 YALE L.J. 1326, 1331 (1963) (noting that "[t]his 'principle of specific performance' is the basic principle of the communist system of contracts" and that "even an express agreement between the parties to a contract concluded under the plan that specific performance will be waived in favor of an equivalent in money is void").

186. Eorsi, supra note 185 , at 154 (noting that socialist law provides for "mandatory liquidated damages" for purposes of raising the level of "contractual discipline"); Grossfeld, supra note 185, at 1341 ("[T]

187. SCHLESINGER ET AL., supra note 140, at 757-58 (explaining that "penalties were charged to a fund which was the source of bonus payments and fringe benefits accruing to managers and workers; as a result, the penalty sanction would be felt by every employee of the enterprise.").

188. See, e.g., TAYLOR WESSING, TAKING AND ENFORCING SECURITY IN EUROPE 1 (2012) ("In 
a powerful remedy, but, as held by the U.S. Supreme Court in Flagg Bros., Inc. v. Brooks, it does not implicate "state action" for purposes of constitutional protection against infringement of rights by the government ${ }^{189}$ Conversely, civil law jurisdictions have traditionally outlawed the realization of collateral out of court as an invalid pacte comissoire. While various civil law countries (including France) have relaxed such restrictions in recent years, numerous exceptions still apply. ${ }^{190}$

\section{Bankruptcy Discharge and "Fresh Start"}

Another systematic difference in contract enforcement across legal traditions relates to the ease with which parties can obtain relief of debt obligations, including contractual obligations, in bankruptcy. In contrast to the analysis so far, we are now shifting gears to focus on institutions that formally belong to bankruptcy, rather than contract, law. Yet there is little doubt that the availability of bankruptcy discharge affects the prospect of contract enforcement in a fundamental way. ${ }^{191}$

Even though rarely examined, the interaction between contract and bankruptcy law can be illuminating. Bankruptcy discharge can be recast as a limitation on the power of the State to provide remedies for breach of contract. As U.S. scholars have noted, "[b]ankruptcy is the ultimate limitation on the state's willingness to force its citizens to pay private debts."

The general thrust of the distinction here is that the common law jurisdictions have more forgiving bankruptcy laws than civil law ones. ${ }^{193}$ In line with their restrictive stance toward contract remedies, common law countries are more liberal in permitting a "fresh start," by which individuals can have their debt obligations discharged after a specified period. ${ }^{194}$

both the U.S. and England the self-help principle applies in relation to enforcement of security and a security-holder can take steps itself to enforce its security," while "[i]n continental Europe, enforcement of security is normally managed through the court and assets are realised by public auction or a courtadministered sale process.").

189. 436 U.S. 149,166 (1978) (holding that, by enacting $\$ 7-210$ of the Uniform Commercial Code, "the State of New York has not compelled the sale of a bailor's goods, but has merely announced the circumstances under which its courts will not interfere with a private sale").

190. For a discussion of the legal regime in France, see Tara Pichardo-Angadi, Pledges Over Inventory: Secured Creditors Can Now Have It Both Ways, NORTON ROSE FULBRIGHT (June 1, 2011), http://www.nortonrosefulbright.com/knowledge/publications/51357/case-review-pledges-over-

inventory-secured-creditors-can-now-have-it-both-ways.

191. While the economic literature has failed to study the existing variation in contract laws, it has repeatedly focused on bankruptcy rules to measure the strength of creditor rights. See, e.g., La Porta et al., supra note 18; Simon Deakin et al., Varieties of Creditor Protection: Insolvency Law Reform and Credit Expansion in Developed Market Economies, 15 SOCIO-ECON. REV. 359 (2017).

192. Teresa A. Sullivan, JAY L. WestbrooK \& Elizabeth WARren, As We Forgive OUR DEBTORS: BANKRUPTCY AND CONSUMER CREDIT IN AMERICA 4 (1989).

193. See, e.g., José Reinaldo Lima Lopes, Consumer Bankruptcy and Over-Indebtedness in Brazil, in CONSUMER BANKRUPTCY IN GLOBAL PERSPECTIVE 91 (Johanna Niemi-Kiesilainen et al. eds., 2003); Giacomo Rojas Elgueta, The Paradoxical Bankruptcy Discharge: Rereading the Common LawCivil-Law Relationship, 19 FORDHAM J. CORP. \& FIN. L. 293, 296 (2014); Nick Huls, A Next Step in Debt Enforcement: The Merger of Debt Help and Debt Collection, 35 J. CONSUMER POL'Y 497 (2012); Johanna Niemi-Kiesiläinen, Consumer Bankruptcy in Comparison: Do We Cure a Market Failure or a Social Problem?, 37 OsGoOde HALL L.J. 473, 502 (1999).

194. Jacob Ziegel, Facts on the Ground and Reconciliation of Divergent Consumer Insolvency 
Bankruptcy proceedings also seem to be more frequent in the common law world. ${ }^{195}$

In the common law world, the United States stands out as by far the most debtor-friendly jurisdiction in a number of dimensions. ${ }^{196}$ As the U.S. Supreme Court famously articulated in Local Loan Co. v. Hunt, one of the primary purposes of bankruptcy law is to give "the honest but unfortunate debtor who surrenders for distribution the property which he owns at the time of bankruptcy, a new opportunity in life and a clear field for future effort, unhampered by the pressure and discouragement of preexisting debt."197 Bankruptcy filing rates in the United States increased precipitously throughout the twentieth century, especially after the more liberal 1978 Bankruptcy Act, surpassing one million filings per year in the mid-1990s. ${ }^{198}$

While some commentators decried the incentives for opportunistic filings by even high-income borrowers, ${ }^{199}$ others praised the role of U.S. bankruptcy law in providing a safety net in the face of a weak welfare State. ${ }^{200}$ Interestingly, bankruptcy law has been a hub for mainstream progressive scholarship in the United States. ${ }^{201}$ By contrast, progressive jurists in civilian jurisdictions are far more likely to focus on judicial review of contract terms and legislative efforts at consumer protection.

The concept of discharge in bankruptcy proceedings is also present in other Anglo-Saxon jurisdictions. ${ }^{202}$ However, a combination of stigma,

Philosophies, 7 THEORETICAL INQUIRIES L. 299, 300 (2006).

195. See Stijn Claessens \& Leora F. Klapper, Bankruptcy Around the World: Explanations of Its Relative Use, WORLD BANK (2002), http://siteresources.worldbank.org/INTLAWJUSTINST/ Resources/Bankruptcy.pdf (finding that, controlling for financial development and macroeconomic shocks, bankruptcy filings are higher in common law jurisdictions); London Econ., Study on Means to Protect Consumers in Financial Difficulty: Personal Bankruptcy, Datio in Solutum of Mortgages, and Restrictions on Debt Collection Abusive Practices, FIN. SERVS. USER GROUP, EUR. COMM'N (2012), https://londoneconomics.co.uk/blog/publication/study-on-means-to-protect-consumers-in-financialdifficulty-personal-bankruptcy-datio-in-solutum-of-mortgages-and-restrictions-on-debt-collectionabusive-practices/ (reporting that the number of bankruptcy filings in the common law jurisdictions covered by the study - the United States, England, Canada, and Australia-was consistently higher than in civilian Germany and France).

196. See, e.g., John Armour, Gerard Hertig \& Hideki Kanda, Transactions with Creditors, in THE ANATOMY OF CORPORATE LAW: A COMPARATIVE AND FUNCTIONAL APPROACH, supra note 7, at 109; DAVID A. SKEEL, JR., DEBT'S DOMINION: A HISTORY OF BANKRUPTCY LAW IN AMERICA 1 (2014) ("U.S. bankruptcy law is far more sympathetic to debtors than are the laws of other nations.").

197. 292 U.S. 234, 244 (1934) (emphasis omitted) (citations omitted). However, the actual effect of a fresh start policy on debtors' efforts remains ambiguous. See Michelle J. White, Economics of Bankruptcy, in OXFORD HANDBOOK OF LAW AND ECONOMICS 447, 471 (Francesco Parisi ed., 2017). But see Kenneth Ayotte, Bankruptcy and Entrepreneurship: The Value of a Fresh Start, 23 J.L. ECON. \& ORG. 161, 162 (2007) (arguing that a fresh start policy fosters entrepreneurship through its effect on post-bankruptcy effort).

198. Michelle J. White, Why It Pays to File for Bankruptcy: A Critical Look at the Incentives Under U.S. Personal Bankruptcy Law and a Proposal for Change, 65 U. CH. L. REV. 685, 685 (1998).

199. Id. at 686.

200. See, e.g., Robert M. Lawless \& Elizabeth Warren, Shrinking the Safety Net: The 2005 Changes in U.S. Bankruptcy Law 1 (Ill. Law \& Econ. Working Papers Series, Research Paper No. LE06-031, 2006), https://ssrn.com/abstract $=949629$ ("The more generous U.S. bankruptcy laws partially compensated for the relatively stingy level of government assistance.").

201. See David A. Skeel, Jr., Vern Countryman and the Path of Progressive (and Populist) Bankruptcy Scholarship, 113 HARV. L. REV. 1075 (2000).

202. Andrew Grossman, Conflict of Laws in the Discharge of Debts in Bankruptcy, 5 INT'L 
procedural hurdles, and judicial discretion has made it significantly more difficult for individuals to obtain discharge in England, Canada, and Australia, compared to the United States. ${ }^{203}$ Even so, when considered along a spectrum, it remains the case that common law jurisdictions have offered a more liberal and accommodating bankruptcy regime than their civil law counterparts. ${ }^{204}$

Civil law jurisdictions have famously adopted a more punitive approach to bankruptcy proceedings, whose primary purpose is to provide an enforcement tool for creditors, not relief for debtors. ${ }^{205}$ At least historically, most civilian countries did not even recognize the concept of individual bankruptcy, and none embraced that of discharge. ${ }^{206}$ So long as a contractual obligation passed muster under the different forms of State control of contract terms, the general consequence was lifelong liability for debts. ${ }^{207}$

To be sure, this field has experienced significant convergence in recent years. On the one hand, a number of civil law jurisdictions, overtly inspired by U.S. law, have come to embrace the idea of bankruptcy discharge in the last decades. ${ }^{208}$ Continental Europe, in particular, has witnessed "a veritable flood of new consumer bankruptcy laws" aimed at affording more generous treatment to debtors. ${ }^{209}$ On the other hand, the enactment of the Bankruptcy Abuse Prevention and Consumer Protection Act of 2005 (BAPCA), prompted by intense lobbying from credit card companies, has made it more difficult for consumers to obtain bankruptcy discharge in the United States. ${ }^{210}$

However, full convergence on a fresh start policy remains elusive. Even though Continental European jurisdictions have progressively embraced the concept of individual bankruptcy and discharge, the differences vis-à-vis the Anglo-Saxon model remain substantial. Consistent with the focus on stronger contract remedies in other areas, the civilian approach typically conditions discharge both on moral judgments as to the origins of the debt and on a multi-

INSOLVENCY REV. 1, 1 (1996).

203. Ziegel, supra note 194 , at 300.

204. Id; see also Charles J. Tabb, Lessons from the Globalization of Consumer Bankruptcy, 30 L. \& SOC. INQUIRY 763, 764 (2005) (reviewing CONSUMER BANKRUPTCY IN GLOBAL PERSPECTIVE (Johanna Niemi-Kiesilainen et al. eds., 2003) and JACOB S. ZIEGEL, COMPARATIVE CONSUMER INSOLVENCY REGIMES-A CANADIAN PERSPECTIVE (2003), and noting that, besides the United States, "[t]he only other countries with a hint of a 'liberal' policy for debtors have been England and its Commonwealth countries, most notably Canada").

205. Nick Huls, American Influences on European Consumer Bankruptcy Law, $15 \mathrm{~J}$. CONSUMER POL'Y 125, 133 (1992).

206. See Niemi-Kiesilainen, supra note 193, at 479 (observing that, until the 1980s, "continental bankruptcy laws did not contain any discharge provisions at all"); Ziegel, supra note 194, at 300 .

207. Huls, supra note 205 , at 133.

208. Huls, supra note 193, at 497 ("Since the 1990s, each Member State of the European Union designed a policy that infused the liberal American fresh start policy into its own social institutions and legal culture."); Iain Ramsay, Comparative Consumer Bankruptcy, 2007 U. ILL. L. REV. 241, 250 ("The U.S. conception of the 'fresh start' has undoubtedly influenced European developments.").

209. Tabb, supra note 204 , at 765 .

210. The new law, among other things, conditioned the availability of immediate discharge of consumers" debt under Chapter 7 of the Bankruptcy Code on a "means test"-a complicated formula designed to assess consumers' ability to repay their debts. Far a description and critical assessment of the reform, see Lawless \& Warren, supra note 200 , at 15. 
year mandatory payment plan. ${ }^{211}$ The distinctions are such that scholars have even constructed different labels to describe these persisting divergences, alluding to the existence of an "earned start" in Europe, in contrast to the "fresh start" of U.S. law. ${ }^{212}$

Overall, it remains the case that common law jurisdictions generally contemplate a more liberal approach to bankruptcy than civilian ones. The question is, then, what explains this divergence? The non-waivable right to bankruptcy discharge is certainly in tension with a strong conception of State support to freedom of contract. Yet, here again, because bankruptcy discharge affects the right to legal enforcement of the obligations in question-but not of its substantive terms - it can be conceptualized as State forbearance in contract enforcement.

So understood, the rise of the fresh start policy (and its variants) appears to be consistent with a less interventionist role for the State. Scholars have long underscored the link between the deregulation of credit markets in Europe and the introduction of consumer bankruptcy discharge, typically by conservative governments. ${ }^{213}$ At the same time as it provides relief, the fresh start is, in the words of Nick Huls, "a mild way of intervening; its implementation demands relatively little interference from the State."214

\section{REAL DIVERGENCE OR FUNCTIONAL SUBSTITUTION?}

As in most comparative endeavors, focusing on individual legal rules and doctrines in isolation can lead one to exaggerate the actual differences among various legal systems. One of the central tenets of modern comparative law is precisely that jurisdictions often reach the same result by relying on different doctrinal formulations. ${ }^{215}$ For instance, at least in theory, one could have expected some degree of functional substitution between the availability of specific performance and the enforcement of penalty clauses. Prominent comparativists have made precisely this argument in asserting that "a legal system which discards or excessively weakens either of the two devices [penalties or specific performance] thereby will become more dependent on the other." 216 Yet this is not what we observe: for all areas of law examined thus far, the civil law requires a stronger role for the State both in the control and in

211. Niemi-Kiesilainen, supra note 193, at 475.

212. Udo Reifner, Johanna Kiesilainen, Nick Huls \& Helga Springeneer, Consumer Overindebtedness and Consumer Law in the European Union, HEALTH \& CONSUMER PROT., EUR. COMM'N 165-67 (2003), www.knl.lv/raksti_data/1147/parskats_ES_2003.pdf. This study, however, groups England and Ireland together with the other EU Member States, even as it acknowledges that, in recognizing discharge, these regimes have been historically closer to that of the U.S. than those of Continental Europe. Id. at 165.

213. See, e.g., Elgueta, supra note 193, at 296; Niemi-Kiesilainen, supra note 193, at 502.

214. Huls, supra note 205 , at 130 (noting that "[d]ischarge of debts is a typical American response to a social problem" and "[ $t]$ he request for a bankruptcy is an individual matter rather than a collective affair").

215. ZWEIGERT \& KOTZ, supra note 4, at 40 (positing the existence of a praesumptio similitudinis - that is, a presumption that different advanced legal systems achieve similar practical outcomes to similar questions).

216. SCHLESINGER ET AL., supra note 140 , at 756-57. 
the enforcement of contract terms compared to the common law.

At a high level of generality, civil law and common law can be viewed as embracing different strategies to mitigate the effects of harsh bargains. While the civil law relies more on standardization and judicial control of contract terms to ensure the fairness of the transaction, the common law instead limits the remedies available in the event of non-performance. To put it differently, it is precisely because the civil law scrutinizes the substance of the transaction that it is willing to enforce it with greater severity. Greater enforcement remedies follow greater "quality control" of terms by the State. The common law, by contrast, is less willing to police the terms of the transaction but, in return, reduces the stakes associated with breaches of contract. While these approaches often lead to disparate results, this is not always the case.

To illustrate this point, consider the famous 1993 decision by the German Constitutional Court (Bundesverfassungsgericht) in the Bürgschaft case, a judgment that became a poster child for German courts' willingness to consider fundamental constitutional rights in the interpretation and enforcement of private contracts. ${ }^{217}$ The Constitutional Court's opinion was framed in terms of the vexing question about the "horizontal effects of constitutional rights" in private relations (Drittwirkung der Grundrechte) - or what U.S. constitutional doctrine calls the "state action" problem. As Mark Tushnet has noted, it is no coincidence that the treatment of this central question in constitutional law is linked to different conceptions about the role of the State, with social democracies being more willing to recognize such horizontal effects than jurisdictions embracing more limited forms of government. ${ }^{218}$

The facts of the case involved a twenty-one-year-old daughter who signed a contract to be a personal guarantor (surety) for her father, a businessman, as a condition imposed by the bank for extending his credit limit from DM 50,000 to 100,000 . In requesting the guarantee, the bank's employee apparently told her: "Would you just sign this here, please? This won't make you enter into any important obligation; I need this for my files."219 The father subsequently defaulted on the loan, and, a few years later, the bank sued the daughter for the

217. Bundesverfassungsgericht [BVerfG] [Federal Constitutional Court] Oct. 19, 1993, 89 ENTESCHEIDUNGEN DES BUNDESVERFASSUNGSGERICHTS [BVERFGE] 214 (229-230) 1994 (Ger.) (translated by author). Specifically, the doctrinal position embraced by the German Constitutional Court has been that constitutional principles do not have direct effect on private relations but instead illuminate the application of the general clauses of civil law. See Bundesverfassungsgericht [BVerfG] [Federal Constitutional Court] Jan. 15, 1958, 7 ENTESCHEIDUNGEN DES BUNDESVERFASSUNGSGERICHTS [BVERFGE] 198 (Ger.).

218. Mark Tushnet, The Issue of State Action/Horizontal Effect in Comparative Constitutional Law, 1 INT'L J. CONST. L. 79, 80 (2003) (positing a "conceptual connection between a nation's constitutional commitment to social welfare rights and the relative ease of the issue of state action/horizontal effect"). Tushnet remarks: "Horizontal direct effect itself can be understood in two ways, each of which captures aspects of the theory of the social democratic state. The political theory of the liberal state sees the powerful state-the public organized into political society-as a real, and perhaps the only real, threat to liberty. Social democracy was in part a response to concern about the effective social power exercised by market actors through their control of valuable social resources such as property and opportunities for employment." Id. at 90-91.

219. Olha Cherednychenko, The Constitutionalization of Contract Law: Something New Under the Sun?, 8 ELECTRONIC J. COMP. L. 1, 3 (2004). 
outstanding principal plus interest, which amounted to DM 160,000. When she signed the guarantee agreement, the daughter had no professional education and no full-time job, earning about DM 1,150 monthly in a fish factory. At the time of the lawsuit, she was a single mother who depended on social security. ${ }^{220}$

Before the case reached the German Constitutional Court, lower courts had found that the guarantee agreement was either contrary to good morals or reflected a violation of the bank's good faith duty to inform its counterparty in the precontractual stage. The higher federal court (Bundesgerichtshof), in turn, held that the foreseeable result of overindebtedness was insufficient to render the guarantee null and void as contrary to good morals. The German Constitutional Court reversed. It held that, in enforcing such an agreement marked by deep imbalances in bargaining power and harsh consequences for the weaker party, the lower courts had denied application of the constitutional rights to human dignity and free development of personality, combined with the principle of the social State. ${ }^{221}$ In the court's view, "there is a violation of the constitutional guarantee to private autonomy when the problem of unequal bargaining power is not even addressed" by courts. ${ }^{222}$

The Bürgschaft decision clearly entailed State interference-no less than through fundamental norms of constitutional law-in the substance of contractual arrangements. In light of the existing imbalance in the parties' bargaining power, the Court undertook to conform the agreement to broader social values and objectives. A closer inspection, however, reveals that a critical element likely motivating the Court's decision was the apparently perpetual or insurmountable character of the obligation in question-akin to a modern "debtor's prison" 223 - and the limitations it imposed on future life choices. ${ }^{224}$ The appellant specifically underscored that she had never earned enough income to pay even the interest due on the loan, so that "one cannot consider that this present relation can ever be terminated."225 Consequently, the reasoning goes, "courts should deny recognition to contracts that so strongly reduce the freedom of action of one of the contracting parties that she can no longer live with dignity."226

Such a limitation on life choices was a direct product of the absence of contractual discharge to individuals under German bankruptcy law at the time. Had the facts of this case taken place in the United States, the daughter-

220. 89 BVERFGE 214 (218-220) (Ger.)

221. Id. at 232 .

222. Id. at 234 .

223. OlHa ChEREDNYCHENKo, FUNDAMENTAL RIGHTS, CONTRACT LAW AND THE PROTECTION OF THE WEAKER ParTY: A COMPARATIVE ANALYSIS OF THE CONSTITUTIONALISM OF CONTRACT LAW, WITH EMPHASIS ON RISKY FINANCIAL TRANSACTIONS 308 (2007).

224. Id. at 255-56 ("DD]espite the fact that, formally, the Constitutional Court resolved the Burgschaft case on the basis of the constitutional right to private autonomy and thus approached the whole issue from the point of view of the fairness of the bargaining process which led to the conclusion of the contract, it appears that in practice its primary concern was extremely burdensome financial consequences for the daughter if the contract would have had to be performed ....").

225. 89 BVERFGE 214 (220-221) (Ger.).

226. Id. at 220 . 
guarantor would likely have had no difficulty in obtaining a fresh start in bankruptcy. That is, the same result--full discharge-would obtain, but through a different route: one based on clear rules that did not require State scrutiny of the merits of contract terms.

The doctrinal paths available to achieve the same result as the German Constitutional Court are not even limited to constitutional principles, general clauses of civil law (such as good faith or good morals), or a fresh start (where available). When confronted with similar facts, the U.K. House of Lords reached the same result. However, instead of appealing to the fairness of the contract or of its effects, it held that there was no contract to begin with, due to a lack of valid assent. In Barclays Bank Plc. v. O'Brien, a wife had agreed to charge the matrimonial home as security for the husband's business debts. The House of Lords allowed the wife to void the transaction based on the notion that this was the type of agreement in which undue influence, duress, and misrepresentation were common - and the bank had not taken affirmative steps to ensure that her consent was indeed free. ${ }^{227}$ In contrast, in Van Lanschot Bankiers v. Bink a Dutch court facing comparable facts also voided the agreement by holding that the bank was under a duty to inform a nonprofessional party of the risks of providing a surety. ${ }^{228}$ While the English and Dutch cases are strikingly similar in their facts and outcomes, it is revealing that the common law court insisted on framing the problem as a matter of assent, as opposed to broad duties of protection to the weaker party of the transaction, a route more compatible with the civil law tradition. ${ }^{229}$

In fact, State intervention in contract terms and omission in enforcement (especially through bankruptcy discharge) can operate as rough substitutes in certain situations. ${ }^{230}$ Take, for example, the problem of dealing with the effects of exogenous risks, such as illness or unemployment, on contract relations. One prominent economic justification for a fresh start in bankruptcy law is that it promotes the efficient allocation of such risks, by shifting it to the party (in this view, the lender) who is best able to bear it. ${ }^{231}$

But even if one agrees that such a risk allocation is desirable from the perspective of efficiency or distribution, bankruptcy is only one of the possible instruments to accomplish this goal. A civilian system may achieve a similar result through the application of contract law-i.e., by employing doctrines

227. Barclays Bank Plc. v. O'Brien, [1993] UKHL 6, [1994] 1 AC (HL) 180.

228. See Cherednychenko, supra note 219, at 4 (discussing HR 1 juni 1990, NJ 1991, 759 m.nt. C.J.H. Brunner (Van Lanschot/Bink) (Neth.)).

229. For a detailed review and comparison of the German, English and Dutch cases examined above, see Cherednychenko, supra note 219 , at 17 (arguing that "it is highly questionable whether the constitutionalization of contract law by means of such constitutional rights as human dignity or party autonomy is indeed something new under the sun and, above all, something which is beneficial for the protection of the weaker party").

230. For an early version of this argument, see George G. Triantis, Contractual Allocations of Unknown Risks: A Critique of the Doctrine of Commercial Impracticability, 42 U. TORONTO L.J. 450, 482 (1992) (arguing that the existence of a fresh start policy in bankruptcy law reduces the need to use contract law as a mechanism to spread risks).

231. See, e.g., Margaret Howard, A Theory of Discharge in Consumer Bankruptcy, 48 OH1O ST. L.J. 1047, 1064 (1987). 
such as good faith to permit the discharge or adjustment of contract terms in light of changed circumstances. The civilian approach may be more tailored to addressing exogenous risk, but it also opens the door to significant (and possibly misguided) judicial discretion. ${ }^{232}$ While the fresh start doctrine does not formally depend on the presence of exogenous risk, a major share of bankruptcy cases reflects precisely this pattern. ${ }^{233}$

Interestingly, progressive scholars in Continental Europe have denounced the rise of bankruptcy discharge, not least because it preempts more socially infused responses in the form of contract law. In a forceful critique of the spread of bankruptcy discharge in Europe, Udo Reifner argued that the fresh start could effectively crowd out the development of "more socially adaptive contract law." 234 In his words, "[t]he reflexive learning model of contract law, which, using good faith and good morals, created labour, tenants and consumer protection law and many other corrective measures guaranteeing its survival in the industrialized society, is gradually given up within legal procedures where judges no longer care about the terms of contracts that have failed." 235 At the same time, "[s]ocially blind contract law leads to straight bankruptcy approaches."236 Therefore, according to this view, the spread of bankruptcy discharge in Europe may be both a product of State deregulation and a shield against further State meddling with contract terms.

Substantive contract terms and remedies can often function as substitutes to achieve the same ends. ${ }^{237}$ This may be one of the reasons why there is no clear winner in the so-called "competition for contract law," to the extent that such competition exists at all. ${ }^{238}$ Although quite different in important dimensions, both English law and Swiss law appear to be the most popular governing laws of choice among sophisticated business parties in international arbitration proceedings. ${ }^{239}$

Beyond that, there are, in fact, good grounds to doubt the rigor of the broader analytical distinction between the substance and enforcement of contract terms from a functional perspective. As Daryl Levinson has argued in

232. But see Triantis, supra note 230 , at $482-83$ (contending that, by distributing the risks among all creditors, a fresh start policy may promote risk-sharing objectives more effectively than contract law, which only distributes the risk among contracting parties).

233. See, e.g., Teresa A. Sullivan et Al., The Fragile Middle Class: Americans in DEBT (2000) (attributing most bankruptcy files to exogenous shocks brought about by factors such as job loss, health problems, and divorce).

234. Udo Reifner, "Thou Shalt Pay Thy Debts": Personal Bankruptcy Law and Inclusive Contract Law, in CONSUMER BANKRUPTCY IN GLOBAL PERSPECTIVE, supra note 193, at 143.

235. Id.

236. Id. at 155 .

237. See Triantis, supra note 176, at 646 (discussing how conditions and damages can operate as substitutes in allocating risk); George G. Triantis, Unforeseen Contingencies. Risk Allocation in Contracts, in 3 ENCYClOPEDIA OF LAW AND ECONOMICs 100 (B. Bouckaert \& G. De Geest, eds., 2000).

238. For the argument that, despite general assumptions to the contrary, no such competition exists in the contract law arena, see Vogenauer, supra note 94.

239. Cuniberti, supra note 115; Stefan Voigt, Are International Merchants Stupid? Their Choice of Law Sheds Doubt on the Legal Origin Theory, 5 J. EMP. L. STUD. 1 (2008). Admittedly, these studies are based solely on data from arbitrations conducted in the International Chamber of Commerce, which introduces inevitable biases. 
the context of public law, rights and remedies are "functionally inseparable"to the effect that " $[w]$ hat matters is the size and shape of the whole rightremedy package. $" 240$ In our terms, while the common law generally offers stronger contract rights, the civil law grants stronger remedies.

Nevertheless, it is noteworthy that U.S. constitutional law doctrine has come to place hefty weight on the distinction between the general terms of the contract, which are the province of private autonomy, and the enforcement measures, which are qualified as state action and scrutinized as such. The differentiation between contract terms and contract remedies has become a touchstone of the U.S. Supreme Court's jurisprudence on the scope of the Constitution's Contract Clause, according to which the states cannot make any laws "impairing the Obligation of Contracts."241 Even as they have acknowledged the analytical difficulties involved, various U.S. Supreme Court decisions have attempted to draw a line between the "obligation of contract," which is subject to constitutional protection against retroactive infringement, and the modulation of the remedy offered by the state, which is not. ${ }^{242}$ It is precisely for this reason that, in order to escape constitutional challenges, legislative relief to U.S. debtors has typically taken the form of modifications to the contract remedy, such as in the numerous instances of moratory legislation during the Great Depression. ${ }^{243}$

The recognition that contract enforcement implicates state action and coercion also constitutes the doctrinal basis for the non-enforceability of racial covenants. In Shelley v. Kraemer, ${ }^{244}$ the U.S. Supreme Court held that judicial enforcement of a contractual provision preventing the transfer of real property to non-whites violated the Equal Protection Clause of the Fourteenth Amendment. The Court's opinion draws a distinction between the "validity of the covenant agreements as such," which is not contested, and the "judicial enforcement of those agreements," which is deemed suspect. ${ }^{245}$ The opinion

240. Daryl J. Levinson, Rights Essentialism and Remedial Equilibration, 99 COLUM. L. REV. $857,858,919(1999)$.

241. U.S. CONST. art. I, $\S 10$, cl. I "("No State shall enter into any Treaty, Alliance, or Confederation; grant Letters of Marque and Reprisal; coin Money; emit Bills of Credit; make any Thing but gold and silver Coin a Tender in Payment of Debts; pass any Bill of Attainder, ex post facto Law, or Law impairing the Obligation of Contracts, or grant any Title of Nobility.").

242. See, e.g., Von Hoffman v. City of Quincy, 71 U.S. (4 Wall.) 535, 553-54 (1866) ("It is competent for the States to change the form of the remedy, or to modify it otherwise, as they may see fit, provided no substantial right secured by contract is thereby impaired. No attempt has been made to fix definitely the line between alterations of the remedy, which are deemed to be legitimate, and those which, under the form of modifying the remedy, impair substantial rights. Every case must be determined upon its own circumstances."); Sturges v. Crowninshield, 17 U.S. (4 Wheat.) 122, 200 (1819) (Marshall, C.J.) ("The distinction between the obligation of a contract, and the remedy given by the legislature to enforce that obligation, has been taken at the bar, and exists in the nature of things. Without impairing the obligation of the contract, the remedy may certainly be modified as the wisdom of the nation shall direct.").

243. J. Douglass Poteat, State Legislative Relief for the Mortgage Debtor During the Depression, 5 LAW \& CONTEMP. PROBS. 517, 520 (1938) ("[T]o avoid constitutional censorship the states have phrased their laws in terms of remedial reform.").

244. 334 U.S. 1 (1948). Shelley remains controversial, and courts have continued to enforce contractual terms that require conduct that the state could not constitutionally impose. See, e.g., Mark D. Rosen, Was Shelley v. Kraemer Incorrectly Decided? Some New Answers, 95 CA. L. REV. 453 (2007).

245. Shelley, 334 U.S. at 9. 
specifically notes that judicial enforcement entails the "full panoply of state power" and the "full coercive power of government." 246 However, despite their lack of judicial enforcement after Shelley, racial covenants continued to promote segregation through signaling and extralegal sanctions. ${ }^{247}$

Determining the effective implications of these different approaches requires further investigation. The relevance of extralegal modes of enforcement in the common law suggests that the civil and common law approaches to mitigating the effects of harsh bargains are unlikely to produce the same outcomes. A fresh start in bankruptcy entails significant reputational costs, such as low credit ratings that can negatively affect access to credit and even employment prospects.

Contract law and bankruptcy law ultimately follow different approaches to the release of contractual obligations: while contract law tackles individual agreements, bankruptcy law addresses them in a collective fashion. Bankruptcy discharge will not assist the party to a draconian deal if she is not insolvent. Conversely, contract law can do little for a poor consumer whose multiple contracts are burdensome in the aggregate but individually fair. Which approach is more efficient and equitable remains debatable.

\section{THE CiviL-COMmon LAW Divide as to THE Role of the STATE}

The idea that common and civil law systems correlate with a different role of the State has a long intellectual pedigree. ${ }^{248}$ Friedrich A. Hayek famously argued that the English common law is more conducive to individual liberty, through a more limited role of the State, than legislature-centered civil law. ${ }^{249}$ In this respect, Hayek echoed nineteenth-century scholars, such as Francis Lieber, who claimed that "Gallican liberty, then, is sought in the government, and, according to an Anglican point of view, it is looked for in a wrong place, where it cannot be found. . . . The question whether this interference be despotism or liberty is decided solely by the fact who interferes, and for the benefit of which class the interference takes place, while according to Anglican views this interference would always be either absolutism or aristocracy ...." 250

246. Id. at 19.

247. See Richard R.W. Brooks, Covenants Without Courts: Enforcing Residential Segregation with Legally Unenforceable Agreements, 101 AM. ECON. REV. 360 (2011).

248. On the contested relationship between legal families and economic efficiency more generally, see Nuno Garoupa \& Mariana Pargendler, A Law and Economics Perspective on Legal Families, 7 EUR. J. LEGAL STUD. 36 (2014).

249. See FrIEDRICH A. HAYEK, THE CONSTITUTION OF LIBERTY (1960) thereinafter HAYEK, THE CONSTITUTION OF LIBERTY]; FRIEDRICH A. HAYEK, LAW, LEGISLATION AND LIBERTY: A NEW Statement of THE Liberal PRINCIPles of Justice and POlitical ECONOMy (1973). For an excellent review of Hayek's arguments on this point, see Paul G. Mahoney, The Common Low and Economic Growth: Hayek Might Be Right, 30 J. LEGAL STUD. 503, 504 (2001) (noting that Hayek "argues vigorously that the English legal tradition (the common law) is superior to the French (the civil law), not because of substantive differences in legal rules, but because of differing assumptions about the roles of the individual and the state").

250. Francis Lieber, Anglican and Gallican Liberty, in 2 MiscellanEOUS WRITINGS 369, 38283 (Daniel Coit Gilman ed., 1881) (emphasis in original); see also HAYEK, THE CONSTITUTION OF LIBERTY, supra note 249 , at 55. 
The same theme reemerged with great force in the prominent line of works that came to be known as the "legal origins" literature. ${ }^{251}$ Starting in the 1990 s, a group of economists (often identified by the acronym LLSV ${ }^{252}$ ) broke new ground in employing the concept of legal families, as defined by comparative lawyers, to measure the impact of legal investor protection on financial development. The idea of legal families originally appeared in LLSV's work as an instrumental variable; as an exogenous source of variation in laws deriving from conquest or colonization in the distant past, legal families could be used to show that laws had a causal impact on financial development, not the other way around. ${ }^{253}$ Using empirical data from a large number of countries, LLSV found that common law countries offered the highest, and French-civil-law countries the lowest, levels of protection to minority shareholders-with German- and Scandinavian-civil-law countries falling in between. ${ }^{254}$

LLSV did not stop at claiming that "law matters" to finance by using legal families as an instrumental variable. ${ }^{255} \mathrm{~A}$ large number of subsequent works went on to show the direct effects of legal origins on various legal and economic outcomes, such as the degree of government ownership of banks and the media, the level of entry restrictions, the regulation of labor markets, and the use of military conscription. ${ }^{256}$ From all these studies, a clear pattern emerges: "civil law is associated with a heavier hand of government ownership and regulation than common law." 257 Even critics of LLSV have recognized a similar pattern in the evolution of corporate, labor, and constitutional law. ${ }^{258}$

These findings appear to be largely consistent with the pattern identified

251. For a review by its main authors, see Rafael La Porta, Florencio Lopez-de-Silanes \& Andrei Shleifer, The Economic Consequences of Legal Origins, 46 J. ECON. LITERATURE 285 (2008).

252. The acronym LLSV refers to Rafael La Porta, Florencio Lopez-de-Silanes, Andrei Shleifer, and Robert Vishny.

253. For original works in this tradition, see La Porta et al., Law and Finance, supra note 18; Rafael La Porta, Florencio Lopez-de-Silanes \& Andrei Shleifer, Corporate Ownership around the World, 54 J. Fin. 471 (1999).

254. The strength of the initial findings was questioned and later rehabilitated by subsequent research. See Simeon Djankov, Rafael La Porta, Florencio Lopez-de-Silanes \& Andrei Shleifer, The Law and Economics of Self-Dealing, $88 \mathrm{~J}$. FIN. ECON. 430 (2008) (revising the coding and confirming the original association between legal origin and investor protection). But cf. Holger Spamann, The "Antidirector Rights Index" Revisited, 23 REV. FIN. STUD. 467 (2009) (revising the initial coding and finding that the results obtained no longer held).

255. While LLSV later came to discredit the use of legal origins as an instrumental variable due to its far-reaching effects, they continued to believe that legal origins are exogenous. La Porta et al., supra note 251, at 298 ("[E]ven if instrumental variable techniques are inappropriate because legal origin influences finance through channels other than rules protecting investors, legal origins are still exogenous, and to the extent that they shape legal rules protecting investors, these rules cannot be just responding to market development.").

256. See, e.g., Juan C. Botero, Simeon Djankov, Rafael La Porta, Florencio Lopez-de-Silanes \& Andrei Shleifer, The Regulation of Labor, 119 Q.J. ECON. 1339 (2004); Simeon Djankov, Caralee McLiesh, Tatiana Nenova \& Andrei Shleifer, Who Owns the Media?, 46 J.L. \& ECON. 341 (2003); Casey B. Mulligan \& Andrei Shleifer, Conscription as Regulation, 7 AM. L. \& ECON. REV. 85 (2005); Rafael La Porta, Florencio Lopez-de-Silanes \& Andrei Shleifer, Government Ownership of Banks, 57 J. FIN. 265 (2002).

257. La Porta et al., supra note 251, at 286.

258. See, e.g., Ahlering \& Deakin, supra note 9, at 899; Reitz, Political Economy and Contract Law, supra note 6 . 
here, with civil law being associated with a stronger, and common law with a weaker, role of the State in contract law. It appears that these different roles often, but not always, lead to different outcomes, as illustrated by the interplay between contract and bankruptcy laws. Further empirical work is necessary to evaluate the practical implications of the observed distinctions.

It is curious that, despite its breadth, the legal origins literature has utterly failed to engage with the most basic or "core" areas of the legal system that comprise the lion's share of legal education. The comparative role of the State in classic legal fields such as contracts, property, and torts has not received much scrutiny. This looks like a missed opportunity. Addressing the gaps in scholarship could contribute to the understanding not only of legal traditions but also of the interdependencies among legal institutions more generally.

In areas that have received such attention from legal scholars, existing legal institutions have been found to reflect disparate arrangements about the role of the State. The seminal work by Mirjan Damaška on systems of civil and criminal procedure-which had a strong influence on the legal origins literature-brings home this point. His comparative analysis of legal processes suggests that the concrete mechanisms associated with different legal traditions reflect fundamentally distinct conceptions about the role of government: while the civil law is devoted to "policy implementation," the common law focuses on "conflict resolution."259 This overarching distinction, in turn, helps transform the "stupendous diversity" in institutional arrangements into an "intelligible" set of patterns. ${ }^{260}$ This Article suggests that similar patterns can be found in contract law doctrines.

But the existence of an association between legal traditions and the role of the State in society does not mean that it is the legal family or origin itself that is doing the work-as Hayek, LLSV, and others imply. My own previous work on the history of corporate law in Brazil, as well as on the broader history of legal families in comparative law scholarship, casts doubt on the assumption that legal families can be truly deemed exogenous. ${ }^{261}$ At least in the Brazilian experience, nineteenth-century lawmakers consciously picked and chose, as well as altered, corporate law rules from a variety of origins to fit the preferences of local elites, not being bound by the foreign models prevailing in any given jurisdiction or tradition. ${ }^{262}$ Recent empirical cross-country studies confirm that legal traditions are, in an important sense, endogenous. ${ }^{263}$

In fact, the very categorizations of legal families that came to dominate

259. DAMAŠKA, supra note 12 , at 11 .

260. Id. at 3.

261. Mariana Pargendler, Politics in the Origins: The Making of Corporate Law in NineteenthCentury Brazil, 60 AM. J. COMP. L. 805 (2012) [hereinafter Pargendler, Politics in the Origins]; Mariana Pargendler, The Rise and Decline of Legal Families, 60 AM. J. CoMP. L. 1043 (2012) (finding that the civil-common law dichotomy was conspicuously absent from comparative lawyers' categorizations until the twentieth century) [hereinafter Pargendler, The Rise and Decline].

262. Pargendler, Politics in the Origins, supra note 261.

263. Carmine Guerriero, Endogenous Legal Traditions (Feb. 9, 2016), http://papers.ssm.com/sol3/papers.cfm?abstract_id $=2444690$ (finding significant evidence of reform of lawmaking institutions over time). 
the comparative law literature-and that were picked up by LLSV-were a product of mid-twentieth-century legal thought. ${ }^{264}$ The classifications floating around in the nineteenth century - a period of strong flows of people, goods, and ideas-looked significantly different from their later counterparts, pointing to considerable flexibility in the choice of legal transplants. ${ }^{265}$ Legal traditions are, to an important extent, "invented traditions." 266

In this view, legal traditions are not the cause but rather the result of distinct styles of social and government organization, which in turn have produced different bundles of institutions. These differences may reflect numerous factors, from culture and religion to particular political forces and historical trajectories. For instance, civil law jurisdictions have faced greater exogenous shocks, as exemplified by the major wars in Continental European territory and the significant levels of economic and political instability in Latin America. ${ }^{267}$

Economic catastrophes can plausibly affect the contours of contract law. France first developed its theory of imprévision to permit the adjustment of the price in a government contract with a power company in view of the soaring coal prices during the ongoing war. ${ }^{268}$ Likewise, German courts' willingness to adjust contract terms in view of changed circumstances famously emerged in response to the country's severe inflationary crisis in the interwar period. ${ }^{269}$

As the previous discussion suggests, contract law provides yet another incarnation of discrepant conceptions about the political economy or the function of the State across legal traditions. ${ }^{270}$ Yet this central area of law has escaped the attention of institutional economists. Consequently, the jury is still out on the concrete consequences of these persistent differences.

\section{CONCLUSION}

This Article has offered a coordinated account of classic differences between the civil and common law of contracts where none presently exists. It shows that various doctrinal distinctions share a similar pattern-with the State playing a stronger role in the civil law and a weaker role in the common lawat both ends of the contracting process (i.e., at both the determination of the

264. Pargendler, The Rise and Decline, supra note 261, at 1055.

265. Id. at 1072 .

266. Id. at 1049 n.23. On the concept of invented traditions, see Eric Hobsbawm, Introduction: Inventing Traditions, in THE INVENTION OF TRADITION 1, 2 (Eric Hobsbawm \& Terence Ranger eds., 1983) ("[I]nsofar as there is such reference to a historic past, the peculiarity of 'invented' traditions is that the continuity with it is largely factitious.").

267. For a related argument in a different context, see Mark J. Roe, Legal Origins, Politics, and Modern Stock Markets, 120 HARV. L. REV. 460 (2006) (arguing that the apparent underdevelopment of stock markets in civil law jurisdictions is attributable to military invasions during the twentieth century, which in turn shaped political preferences).

268. The theory traces back to the prominent decision involving the Compagnie génerale d'éclairage de Bordeaux. Conseil d'État, [CE] [highest administrative court] Mar. 30, 1916, 59.928, Rec. Lebon 125 (Fr.).

269. SHIRLIY RENNER, INFLATION AND THE ENFORCEMENT OF CONTRACTS 11 (1999).

270. For excellent work discussing the relationship between the political economy and various legal institutions, see Reitz, Political Economy and Comparative Law, supra note 6. 
content of the agreement and at the provision of remedies to the aggrieved promisee in the event of a breach). In the common law, there is greater need for private ordering all the way, including with respect to extralegal modes of enforcement. The comparatively strong degree of State support to private contracts in the civil law defies the typical stereotypes in the contract literature, but it is otherwise consistent with the broader distinctions between these legal traditions in other areas of the law.

This is, however, but a first step in the effort to revitalize the study of the comparative law and economics of contract law, an area that is unjustifiably underdeveloped for three sets of interrelated reasons. ${ }^{271}$ First, works by comparativists on contract law continue to suffer from the persisting "malaise"272 plaguing comparative law as a discipline more generally, in which most works identify observed differences but do not explain them. Second, in contrast to other areas of comparative inquiry, there is still a dearth of studies seeking to understand the relationship between the nature of contract law in a given jurisdiction and other political and economic structures. Finally, economists continue to operate under the untested assumption that, while "contract institutions" matter deeply for economic development, the nature of contract law itself does not. The emphasis on procedural matters of contract enforcement has not translated into an interest in the substance of what is enforced, to the effect that contract law remains largely a "black box.",273

Yet, a priori there is no reason to accept this presumed irrelevance of contract law for the economy or society more generally. ${ }^{274}$ Clearly, the law of contracts of developed countries is not perfect, ${ }^{275}$ but neither is the regime of any other legal field. Moreover, the fact that the economic analysis of contract law is both indeterminate and unsuccessful in predicting the content of legal doctrines ${ }^{276}$ further suggests that there are other factors shaping institutions.

The analysis here looked beyond traditional disciplinary boundaries to include institutions of bankruptcy law that have an impact on contract enforcement. Yet the existing institutional interdependencies involving contract law are likely to be even broader, also encompassing fields such as security interests, property, and even the strength of the welfare State. ${ }^{277}$ Institutional interdependence may lead to functional substitution and, as such, to smaller practical differences than appear at first sight. At the same time, calls for convergence on a single dimension-e.g., for lesser State interference in

271. See Pargendler, supra note 86 (calling for further work in this area).

272. Valcke, supra note 6.

273. Goldberg, supra note 110, at 270.

274. Pargendler, supra note 86.

275. Goldberg, supra note 110 , at 251 ("[T] reasonably well even with law that is pretty bad.").

276. See, e.g., Eric Posner, Economic Analysis of Contract Law After Three Decades: Success or Failure?, 112 YALE L.J. 829 (2003).

277. For another example of a potential interaction, see Eric Posner, Contract Low in the Welfare State: A Defense of the Unconscionability Doctrine, Usury Laws, and Related Limitations on the Freedom To Contract, 24 J. LEGAL STUD. 283 (1995) (suggesting, as a matter of theory, that limitations on freedom of contract are efficient in the presence of a welfare system). 
contract terms in the civil law-may lead to further divergences in the absence of complementary changes. 
